\title{
Osmanlı Tarihinin İlk Büyük Savaş Anlatımı: Osmanlılarla Karamanlılar Arasındaki Frenkyazisı Muharebesi (1386/1387)
}

\author{
Feridun M. Emecen*
}

The Earliest Narrative of a Major War in Ottoman History: The Battle of Frenkyazist between the Ottomans and the Karamanids (1386/1387)

Abstract - The first narrative of a major pitched battle based on Ottoman sources dates back to the reign of Murad I. A detailed book of victory/conquest (zafernâme) fetihname) on the Battle of Frenkyazisı, which took place between the Ottomans and the Karamanids a couple of years before the Battle of Kosovo (late 1386 - early 1387), survived in the history of Neşri, one of the early Ottoman chronicles penned in the fifteenth century. This battle was not touched upon by Âşıpaşazâde, another early Ottoman chronicler. İbn Kemal and İdris-i Bitlisî, two historians writing later than Neşrî, however, mentioned it in their works. Moreover, some anonymous Ottoman chronicles and Behiştî described the battle briefly. It should also be added that Neşrî, İbn Kemal and İdris-i Bitlisî did not rely on each other; their account should rather be based on an another text. On the other hand, the Karamannâme of Şikarî, a sixteenth-century source reflecting the Karamanid point-of-view, presents an alternative approach. Şikarî’s narrative is consistent with Ottoman narratives along general lines, if not in detail. The information included in these chronicles has a special significance because the Battle of Frenkyazısı demonstrates the transformation in classical Ottoman warfare before the Battle of Kosovo. These texts point to the emergence of a divergence between the Ottoman system based on infantry and classical Turcoman tactics. Finally, the battle paved the way for the Karamanid acknowledgement of Ottoman superiority.

Keywords: Ottoman-Karamanid relations, Ottoman warfare, the Battle of Frenkyazısı, Murad I, Karamanlı Alaeddin Beg, Konya.

* İstanbul 29 Mayı Üniversitesi 
Anadolu'da Selçuklu hakimiyetinin inkiraza uğramasıyla doğan beylikler içinde en önemli yere sahip olanı hiç şüphe yok ki onun mirasını üstlenme iddiasıyla da hareket eden Karamanoğulları Beyliğidir. Aslında basit bir "beylik"ten çok müesseseleriyle tekemmül etmiş bir "devlet" yapılanması içinde olduğu anlaşılan Karamanoğulları, Osmanlı beyliğinin de içinde bulunduğu Batı Anadolu beyliklerinden hayli farklı bir tarihî sürece sahip olarak gelişme göstermişe benzemektedir. Her şeyden evvel Karamanlılar merkezi bir siyasî teşekkül olarak Selçuklular'dan sonra bütün Anadolu beyleri üzerinde üstünlük iddiasını açık şekilde sürdüren ve hatta bunu başlangıçta kabul ettiren kudret sahibi beylik veya daha doğru tabirle bir "devlet” özelliğini haiz olmuştur. Onların güçlü bir beylik olarak sivrilmeleri sonucu, bölgedeki siyasî kararsızlıkların nispeten ortadan kalktığı daha dengeli bir ortam doğduğu da söylenebilir.

Karamanoğulları'nın merkezî konumda olmalarının ve bunun tabii bir sonucu olarak bu kesimde metbûiyet iddiasını sürdüren büyük devletlerin (mesela önce İlhanlılar sonra Memlükler) baskılarını dâimâ üzerlerinde hissetmelerinin, siyasî ve askerî bakımdan onları zamanla belirsizlikler ve zorluklar içinde bıraktığını düşünmemek için bir sebep yoktur. Bu durum bastırdıkları paralara kadar da yansımış gözükmektedir. ${ }^{1}$ Osmanlılar ile olan rekabette bu belirsizliklerin özellikle gelecekteki varlıklarını idame açısından- Karamanoğulları için sürekli hatırda tutulacak bir anlam kazanmaya başladığını iddia etmek ve ilişkileri bir de bu çerçeveden okumak bilinen yaklaşımlara, yorumlara muhtemelen farklı bir veçhe verecektir.

Bu yazıda Karamanoğulları üzerinde başlayan Osmanlı baskısının ilk görünür hadisesi olan ve önemli bir siyasi kırılmaya yol açan Frenkyazısı Savaşı üzerinde durulacaktır. Bu savaş sadece siyasi anlamda değil, aynı zamanda en erken Osmanlı kroniklerindeki ilk mufassal meydan savaşı anlatımı olmak itibarıyla da Osmanlı tarihçilik anlayışı içinde farklı bir yer edinmektedir. Bu savaşın orijinal anlatımını ihtiva eden metin, II. Bayezid dönemi başlarında ortaya çıkan ve derleme bir Osmanlı kroniği olduğu bilinen Neşri' nin Cihannüma adlı tarihi içinde yer almakta; ilk dönem Osmanlı savaş usulleri hakkındaki bilgileri belirli bir yere oturtacak önemi haiz görünmektedir. İki Anadolu beyi arasındaki bu meydan muharebesi, Osmanlıların temsil ettiği ve piyadenin de ağırlıklı rol oynadığı

1 Karaman paralarında kendi beylerinin adları yanında mesela Memlük sultanının adı da vardır. Tesbit edilebilen ilk paranın 1315 yılına ait olduğu ve İbrahim Bey ile Memlük sultanı el-Melikünnasır’ın adını taşıdığı bilinmektedir: Genel olarak bk. Cüneyt Ölçer, Karamanoğulları Beyliği Madeni Paralar, İstanbul 1982. 
yeni savaş sistemiyle Karamanlıların ananevi süvariye dayalı çarpışma usullerinin şimdilik yazılı metinlere akseden ilk karşılaşması olarak burada takdim edilmek istenmektedir. Ayrıca olayın bizatihi bu özelliği yanında ilk Osmanlı tarihçilerinin hadiseye bakışları ve ele alış biçimleri, eldeki ilk orijinal metne aradan geçen zaman zarfında kendi dönemlerindeki anlayışlara uygun olarak nasıl müdahale etmiş bulundukları gibi hususlar üzerinde de yeni bazı argümanlar ortaya konulmaya çalışılacaktır.

\section{İlk Osmanl1-Karaman Siyasî İlişkilerine Giriş}

Frenkyazısı Savaşı'na geçmeden önce ilk Osmanlı Karaman münasebetlerinin tarihi seyrine kısaca göz atılacak olunursa, iki beyliğin XIV. yüzyılın ilk yarısındaki durumunu ve bu savaşın nasıl bir kırılmaya yol açtığını anlamak daha kolay olacaktır: Karamanlıların Konya'ya tam olarak hakim olduktan sonra esas itibarıyla Selçuklu varisi gibi hareket ederek Anadolu beylikleri üzerinde baskı oluşturdukları ve onların kendilerine bağlı olması gerektiği yolunda meşruiyet arayışları içinde bulundukları bilinmektedir. Bu tür hak iddiaları, Selçuklular'ın soyundan gelmekten çok (yani irsî değil) siyasî bir mirasın ifadesi olarak anlaşılmalıdır. Bu bakımdan Karamanlıların diğer beylikler ve bu arada giderek bulunduğu bölgede büyüme eğilimi gösteren Osmanoğulları'na karşı olan tutumlarını Osmanlı tarih yazımının etkisinin dışında olarak daha "serinkanlı bir anlayışla" değerlendirmek elzem görünür.

1357'de veya 1361'de Alaeddin Ali Bey'in Karamanlı tahtına geçişiyle Karamanoğulları tarihinde yeni bir devir başlamıştır. ${ }^{2} \mathrm{Bu}$ dönem aynı zamanda gücünü önemli ölçüde ikameyi başarmış olan Osmanoğulları için de farklı bir devreye işaret eder. Nitekim Osmanlılar ile Karamanoğulları arasındaki ilk ciddî siyasî münasebetlerin bu zamana denk düştügüne dair bilgiler, artık literatürde yavaşça yerini alacaktır. ${ }^{3}$ Feridun Ahmet Bey'in Münşeat ındaki 1 Rebiülahır 767

2 Onun dönemi ve mücadeleleri için bk. Yahya Başkan, "Karamanoğulları Beyliği Alaeddin Ali Bey Dönemi, 1357-1398”, Karaman Tarihi ve Kültürü, III, Karaman Valiliği, (baskı yeri ve tarihi yok), s. 381-462.

3 Orhan Bey döneminde de bazı mektuplaşmalara dair kayıtlar varsa da bunların mevsukiyeti hakkında kesin hüküm verilememektedir. Bunların çoğunun aradaki dostlukla ilgili olmaları ve hitaplardaki bazı karineler, tarihî çizgiye uyum gösterir (Mesela bk. Feridun Bey, Münşeatüs-Selâtin, İstanbul 1274 I, 66, 80-85, 86-87; I. Beldiceanu-Steinherr, Recherches sur les actes règnes des sultans Osman, Orkhan et Murad I, Monachii/ Münih 1967, s. 149-151, 154-155, 157). Orhan Bey’e ait ilk mektupta oğlu Süleyman 
(16 Aralık 1365) tarihini taşıyan I. Murad'ın Alaeddin Ali Bey'e Rumeli yakasına gaza için geçtiğini bildiren Farsça mektubu "dostane" ilişkiler bakımından manidardır. ${ }^{4} \mathrm{Bu}$ haberleşmelerle başladığı anlaşılan "resmî nitelikli" yakınlaşmalarda, Alaeddin Ali Bey'in genişleme siyaseti ve beylikler üzerinde otorite tanıtma arayışları belirleyici olmuşa benzemektedir. Anadolu'da diğer beylikler gibi "durağan” değil genişleyen iki beyliğin birbirine rakip olmaması bu şartlar altında şüphesiz beklenemezdi. Her iki beyliğin genişleme politikalarından rahatsız oldukları anlaşılan küçük beylikler bu iki güç arasındaki ilişkilerde ve çatışmalarda anahtar rol oynamışlardır.

Bulundukları bölgede hakimiyetlerini kurup Rumeli yakasına gazaya giderek şöhret kazanan Osmanlılara karşı Karamanlılar'ın takındığı "düşmanca" tavır ile ilgili kaynaklara akseden ilk bilgilerin I. Murad devrine rastlaması dikkat çekicidir. Osmanlı Karamanlı münasebetlerinde daha 1361'de Osmanlı karşıtı bir ittifakın Karamanlılar tarafından oluşturulduğuna dair bazı rivayetler mevcuttur. ${ }^{5}$ Ancak o yıllardaki şartlara bakıldığında bunun sebebi müphemiyet içinde kalır. Bazı tarihçiler bunu I. Murad'ın Hamidoğulları'na ait Yalvaç, Karaağaç gibi yerleri satın

Paşa’nın Gelibolu’ya geçip Trakya fetihlerinden bahis vardır ve Karamanoğlu'nun bu gazaya katılma isteğine olumlu cevap verilmiştir. Bu mektuba karşılık gelen cevapta Karamanoğlu kardeşlerinin kendine yönelik harekatı sebebiyle asker yollama niyetini gerçekleştirememekten dolayı üzüntülerini beyan etmiştir.

4 Bu mektupta I. Murad Alaeddin Bey'e biraderim şeklinde hitap ederken onu "noyan-1 a’zam" şeklinde de anar ki bu unvan Moğol etkisinin "serpintileri” olarak çok önemlidir. Ayrıca bu ilk döneme ait mektupların mevsukiyeti bakımından da şüpheleri nisbî de olsa giderici bir işarettir. Yani bu mektubun doğru olma ihtimali yüksektir, yalnız tarihinde bir hata olması muhtemeldir. Mektubun yazılışı itibarıyla I. Murad'ın tahta cülusu sırasına 1361 veya 62'ye denk düşmesi daha uygun olacaktır (Münşeat, I, 90-91). Zira mektupta Edirne'ye kadar olan Trakya arazisi üzerindeki kalelerin ele geçirilmesinden bahsedilir. Ayrıca bu mektubun analizi için bk. I. Beldiceanu-Steinherr, Recherches sur les actes règnes des sultans Osman, Orkhan et Murad I, s. 169-170.

5 Mesela ilk devir belgeleri konusunda ciddi şüpheler uyandıran Feridun Bey’in münşeat mecmuasında I. Murad'ın tahta çıkmasından sonra Edirne'nin fethi münasebetiyle "Acem şahı Üveys'e" (Celayirli Şeyh Üveys: ö. 1374: bk. V. Minorsky, "Üveys", $\dot{I} A$, XIII, 133-134) yolladığı mektuba karşı taraftan verilen Rebiülevvel 763/ Aralık-Ocak 1361-62 tarihli cevapta Murad'ın tahta çıktığında bazı zorluklarla karşılaştığından ve bu meyanda Karamanoğlu'nun fesadından söz edilmektedir (Münşeat, I, 91-92). I. Murad'ın tahta 1362 Martında çıktığı genel olarak kabul edilmektedir. Böyle olunca burada yer alan tarih problemli hale gelir. Ancak bu tarihi hemen reddetmeden önce I. Murad'ın cülusu meselesini yeniden düşünmek gerekir kanaatindeyim. 
almasına bağlar: ${ }^{6}$ Alaeddin Bey bunu hazmedememiş ve I. Murad Balkanlar'da iken Karaağaç, Eğridir ve Yalvaç'1 işgal etmiştir. Bu hadise kroniklerde nispeten "tarihsiz" bir devre olarak yani kronolojik çerçeveden bağımsız şekilde yerini aldığına göre ciddi bir karıştırmanın veya anakronik yaklaşımların yahut meşruiyet bahanelerinin dayanağı olacak şekilde muhayyel bir ifadeye istinat edebilir. Fakat aşağıda temas edileceği gibi üzerinde yeniden düşünmeyi hak edecek önemdedir. Bundan sonra kaynaklarda Eretnaoğlu Mehmed ile Turgud, Varsak oymakları dahil oluşan ittifakın hedefinin Bursa ve İznik olduğu nakledilir ki bunun da Osmanlı siyasetinin meşru zeminlerde önünü açmaya yönelik manevra olmak üzere özellikle zikredilmiş bulunma ihtimali yüksektir.

Aslında 1359'dan itibaren Karamanlılar Latinler'in elindeki Gorigos'a (SilifkeKız Kalesi) yönelik sefer tasarlamakta ve bu yöredeki gelişmelere dikkatlerini yöneltmiş bulunmaktaydılar. Alaeddin Ali Bey’in bütün Türkmen beyliklerini topladığı bir gövde gösterisine dönüşen nihai sefer, yıldızı artık hayli yükselmiş bulunan Osmanlılar ile olan rekabet açısından da belirleyici bir özellik taşır. 1367'de bütün Türkmen beylerinin gözü önündeki bu seferde uğranılan başarısızlık, Osmanlıların söz konusu rekabette birden öne çıkmalarına vesile teşkil etmiş olmalıdır. ${ }^{7}$ Kanaatime göre bu ilk münasebetler ve rekabet ortamı ile münasebetlerdeki düşmanlık ve Osmanlı gücünün giderek daha fazla hissedilmeye başlanmasında bu olay âdetâ bir dönüm noktası olmuştur. ${ }^{8}$ Zira olayların seyri bu tarihten sonra Karamanlılara karşı onlara sözde inkıyat göstermiş görünen diğer komşu beyliklerin başkaldırıcı hareketlere tevessül etmeleriyle daha da açık hale gelmiştir. Nitekim Eretnalılar ve Hamidoğulları ile Germiyanlar'ın faaliyetleri bu anlamda dikkat çeker.

6 Sait Kofoğlu, "Hamidoğulları”, Di், XV, 473-474. Konuyla ilgili ayrıca bk. F. M. Emecen, Osmanlı İmparatorluğu'nun Kuruluş ve Yükseliş Tarihi (1300-1600), İstanbul 2015, s. 73-74.

7 Şehabettin Tekindağ, "Karamanlılar'ın Gorigos Seferi (1367)”, Tarih Dergisi, 6 (1954), s. 161-174.

8 I. Murad'ın Germiyanlılarla başlayan akrabalık ve toprak kazanımı, dügün meselesi, kız vererek akrabalıklar tesis etme siyaseti dikkat çekicidir. Karamanoğlu ile de aynısını yapmış, kızını (Nefise/Melek Sultan) Alaeddin Bey’e vermişti (nikah akdi ve hediyeleşme ve cehiz/kalın, başlık ile ilgili resmî yazışmalar Münşeat, I, 104-105'de yer alır. Fakat buradaki tarih yanlış olmalıdır. Zira Nefise Hatun'un Karaman/Larende'deki medresesi kitabesinde inşa tarihi 783(1381-82)'tür. Evliliğin 1370 dolayında olması daha makuldür: Faruk Sümer, "Alaeddin Bey”, DİA, II, 321-322). Muhtemelen Murad güçlü beyliklerle akrabalık bağı tesis etme politikası izliyordu. Bunun altında yatan sebepler, birlikte hareket edebilme ve zamanla Osmanlı gücünü hakim kılabilme anlayışına dayanıyor olabilir. 
Özellikle tarihi kayıtlara inanmak lazım gelirse Germiyan ve Hamidoğulları arazilerinin Osmanlılara intikali meselesi, bir ölçüde Karamanlıların tavrını test etmeye yönelik önemli bir gelişme olmuştur ve tarihen de yukarıda sözü edilen dönemden ziyade bu son devirle ilişkili bulunmalıdır. Nitekim Münşeat'taki mektuplarda bu hadiseye dair bilgiler olması, yaşanan rekabetteki temel sebepler bakımından söz konusu "satın alınan topraklar" meselesinin/çekişmesinin belirleyiciliğini nispeten ortaya koyar. Doğru olma ihtimali yüksek olan bu yazışmalarda Seydişehir hâkimi Mahmud Bey'in, I. Murad'a ait olan ve vaktiyle Hamid-ili beyi Hüseyin Bey'den satın alınmış bulunan Beyşehir, Seydişehir, Yalvaç ve Karaağaç' in Karamanlılar tarafından yağmalanması hadisesini Osmanlılara bildirdiği mektup bu açılardan manidardır. Alaeddin Ali Bey'in bu harekete girişme iddiasını "bu toprakları vaktiyle I. Murad'dan satın almış olmasına" bağlaması önemlidir.' Alaeddin Bey savaştan az önce, bu hareketinin sebebini açılamak için "pederim" diye hitap ettiği I. Murad'a gönderdiği bir mektubunda, Hamidili hâkimi Hüseyin Bey'in Seydişehir ile Beyşehir'i I. Murad'a satarken Karaağaç, Yalvaç ve etrafındaki bazı yerleri de kendisine sattığı iddiasında bulunmuştu. Yani kendisine ait bu topraklarda Osmanlılara tabi Seydişehir hâkimi Mahmud Bey'in işgalci konumunda olduğunu ileri sürüyor, ona karşı hareketinin sebebini bu "şer'i/kanunî hakka" bağlıyordu. ${ }^{10}$ Böylece Osmanlı kroniklerinde Frenkyazısı Savaşı'nın gerçek sebebinin bu olayla doğrudan bağlantılı olarak anlatılması -kronik yazarlarının kendi argümanları açısından- makul bir meşru gerekçe sunar.

Osmanlı-Karaman ilk savaşı, muhtemelen bu gelişmelerin ardından Konya önlerinde vuku bulmuştur. Aşağıda değerlendirilecek olan bu ilk büyük meydan savaşındaki Osmanlı başarısı, 1367'de Karamanlıların Gorigos seferiyle başlayan sürecin son halkasını oluşturmuşa benzemektedir. Zira Karamanlılar ilk defa Osmanlı üstünlüğünü kabul etmek zorunda kalmışlardır. Böylece vasal bir statüyü de kabullenmişlerdir ki bu da onların imajını sarsacak ölçüde ağır sonuçlara yol açmış olmalıdır. Karamanlılar için Osmanlılar büyük ihtimalle bu tarihten sonra gerçek anlamda bir "tehlike ve tehdit" unsuru haline geldiler ve mücadeleyi ısrarla sürdürecekleri bir döneme girdiler. Bundan dolayı neticeleri itibarıyla bu

9 Mahmud Bey'in Karamanoğlu Alaeddin Ali'den şikâyet mektubunda tarih yoktur: (Münşeat, I, 109-110). Ancak bunun hemen sonrasında I. Murad'in seferberlik emri evâhir-i Ramazan 788 (1386 Ekim ortası) tarihini taşır ki, Frenkyazısı Savaşı'nın hemen arifesini işaret eder (I, 110; krş. I. Beldiceanu-Steinherr, Recherches sur les actes règnes des sultans Osman, Orkhan et Murad I, s. 226).

10 Münşeat, I, 110. 
ilk savaşın mahiyeti son derece önemlidir. Osmanlı Karamanlı mücadelesinin kaynaklara ayrıntılı olarak yansıyan ilk görünür olayı "Frenkyazısı" Savaşı, siyasî sonuçları itibarıyla Karamanlıları bir süre için de olsa Osmanlı vasali yapmakla kalmamış, ayrıca askerî açıdan Osmanlı üstünlüğünün niteliğini -bilhassa I. Kosova öncesi taktik ve uygulama bakımından- açık halde göstermiştir.

\section{Frenkyazısı Savaşı'nın Anlatımı}

Savaş ve I. Murad'ın Karaman harekatı ile ilgili en geniş bilgi Osmanlı tarihçisi Neşrî̀nin, onunla çağdaş sayılabilecek İdris-i Bitlisînnin, İbn Kemal'in (Kemalpaşazâde) ve alternatif bir anlatımla Şikârî̀nin eserlerinde yer alır. Ayrıca onlarla çağdaş Behiştî Ahmed Çelebi de muhtemelen Anonim Osmanlı tarihlerinden birini esas alıp yüksek bir edebî dille süslemiş gözükmektedir. ${ }^{11}$ Bunların dışında ayrıntılı tasvirlere rastlanmaz. ${ }^{12}$ Mesela ilk Osmanlı tarihçilerinden Âşıkpaşazâde ve Oruç Bey bu seferden hiç söz etmezler. Âşskpaşazâde’nin bu tavrı ilginçtir, bu olayı anlatmaması eğer teknik bir sebebe mebni değilse o vakit bunun altında başka ahlakî veya siyasî sâik aramak gerekir. ${ }^{13}$ Bunu şimdilik bir

11 Behiştî Ahmed Sinan, Târîh-i Âl-i Osmân, İstanbul Araştırmaları Enstitüsü Ktp., Şevket Rado Yazmaları, nr.293. Behiştî̀nin bugüne kadar bilinen eseri Yıldırım Bayezid'den II. Bayezid dönemi ortalarına kadar gelen kısım olup yakın zamanda yayımlanmıştır: Târîh-i Behiştî: Vâridât-ı Sübhânî ve Fütûhât-ı Osmânî (791-907/1389-1502), II, haz. Fatma Kaytaz, Ankara 2016. Eserin Osman, Orhan ve I. Murad devrini ihtiva eden söz konusu yazma nüshası da yine F. Kaytaz tarafından yayıma hazırlanmıştır. Bu yazmadaki Frenkyazısı Savaşı'yla ilgili bilgiyi benimle paylaştığı için kendisine teşekkürü borç bilirim.

12 Mesela geç dönem tarihçilerinden Hoca Sadeddin Efendi, İbn Kemal ve İdris-i Bitlisîn nin eserlerini görmüş olarak konuyu ele almış olmakla birlikte daha muhtasar bir anlatımı tercih etmiştir: Tâcü̉t-tevârih, İstanbul 1279, I, 103-108. İdris-i Bitlisî̀nin Türkçe tercümesine bile bakıldığında Tacüt-tevârib’le hemen hemen aynı olduğu anlaşılacaktır: Heşt Bihişt (Abdülbaki Sadi Efendi tercümesi), haz. M. Karataş-S. Kaya-Y. Baş, Ankara 2008, I, 364-371; ayrıca Heşt Bihişt in orijinal kısmı için bk. Nuruosmaniye Ktp., nr. 3209, 150b-153a. Ayrıca eserlerini II. Bayezid döneminde veya hemen sonrasında kaleme almış olan diğer bazı tarihçilerin mensur ve manzum eserlerinde de bu savaştan kısaca bahsedildiği bilinmektedir (Mesela bk XV. yy. tarihçilerinden Kemal, Selâtin-nâme, haz. N. Öztürk, Ankara 2001, s. 65-66). Bunlar da daha çok Neşrî̀yi ve İdris-i Bitlisî̀yi esas almış görünmektedir.

13 Âşıkpaşazâde’nin bu savaş ile ilgili Ahmedî̀nin yazdıklarını görmemiş olması beklenemez. Bu kaynağı kullandığı halde niçin bu savaşı sessizce geçiştirdiği konusu üzerinde tekrar düşünmeyi hak ettirecek önemdedir. Bunda Fatih Sultan Mehmed 
tarafa bırakarak Âşıkpaşazâde'nin de gördüğü ve kullandığını bildiğimiz ilk Osmanlı tarihçisi olan Ahmedî̀den başlarsak, onun Karamanlılarla olan bu savaşı anlattığını, ancak şiir diliyle kaydettiği bu mücadele hakkında hayli yetersiz bilgi verdiğini görürüz. Mesela savaşın sebebi zikredilmemiştir ve "Karaman şahının Murad Bey ile ceng etmek istediği" ibaresiyle söze başlanır. ${ }^{14}$ Ahmedînnin tezi, Karamanoğlu’nun yanına “Tatar/Moğol, Varsak, Turgud, Türk, Rum, Şam’ın” yer alması, onun Murad'a düşmanlık göstermesidir. Murad bunu işitince harekete geçmiş, kimseden yardım istemeksizin onlarla harp etmiş, hepsini bozguna uğratmış ve Karaman Beyi kaçıp gitmiş, bunun üzerine Murad da kâfir memleketlerine yeniden yönelmiştir. İlginç olan husus Ahmedî̀nin Karamanlılar ile Memlükleri ilişkilendirecek ölçüde Osmanlı karşıtı müttefikler içinde "Şam"ı da zikretmekte olmasıdır. Bunun Yıldırım Bayezid döneminin, Memlük karşıtı havasından mülhem bulunma ihtimali yüksektir. Yıldırım Bayezid'in Memlükler'in idaresi altındaki Malatya’ya kadar uzandığı düşünülecek olursa, bu atmosferin Ahmedîye böyle bir eklentiyi yapma fırsatı vermiş olması mümkün görünmektedir. ${ }^{15}$ Ahmedî ile çağdaş olan Osmanlı dışı bir kaynak olarak Bezm ü Rezm’de savaşın ayrıntısına girilmeksizin "Osmanoğlu’nun karınca sürüsü gibi kalabalık ordusunun Karaman’a yürüdüğ̈̈nün” haber alındığı, bunu duyan Kadı Burhaneddin’in Karamanoğlu ile savaşmak için Develi'ye kadar gelmişken onurlu bir hareketle Osmanlılar tarafından ezilmiş olan bir ülkeye girmediği, bu sırada Karaman elçisinin gelip özür dilediği, bir anlaşma yapıldığı ve Kadı Burhaneddin'in geri döndüğü anlatılır. ${ }^{16}$ Ayrıca Osmanoğlu’nun bu harekattan sonra Eğridir’i alıp geri

dönemindeki kul asıllı idarecilerle Karaman menşeli grup arasındaki rekabetin etkisi olabilir. Âşıkpaşazâde'nin Zeyniyye tarikatı mensubu olarak başka hassasiyetlerin peşinde koşmuş olma ihtimali de yüksektir.

14 Osmanlı Tarihleri, İstanbul 1939, s. 15-16.

15 Burada hemen Ahmedînnin bu kısımları yazarken eserini Yıldırım Bayezid'e takdim etmiş olduğunu hatırlatmalıyız. Yani Ahmedî, Yıldırım Bayezid'e uğraşa girdiği Memlükler’in zaten Osmanlı karşıtı ittifaklarda bulunduğunu ima etmiş oluyordu. Ankara savaşından sonra Ahmedî söylem değiştirmekle birlikte yazdığı kısımlarda herhangi bir tadilata girişmemiş, eserini Emir Süleyman'a takdimi sırasında onu övücü ve Yıldırım'ı suçlayıcı imalara yer vermiştir. (Bunun için bk. F. M. Emecen, "İhtirasın Gölgesinde Bir Osmanlı Sultanı: Yıldırım Bayezid”, Osmanlı Araştırmaları, 43 (2014), 74-75).

16 Aziz b. Erdeşir-i Esterâbâdî, Bezm ü Rezm, trc. Mürsel Öztürk, Ankara 1990, s. 292293: Kadı Burhaneddin, bu sefer vesilesiyle Osmanlılarla bir anlaşması varmış gibi müttefikane hareket etmiş şekilde görünmekten kaçınmıştır. Gerçekte I. Murad ile pek iyi bir ilişki içinde olmadığı açıktır. Muhtemelen Osmanlılar daha önce hareket ederek 
döndüğü ifade edilir. Bu kısa bilgiler Frenkyazısı Savaşı'nın çağdaş ve Osmanlı dışı bir kaynaktan teyidi anlamına gelir.

Geç tarihli "erken Osmanlı tarihlerine" dönersek: eserini Fatih Sultan Mehmed döneminde kaleme alan Şükrullah, I. Murad'ın Ankara'ya uzanıp orayı almasının ortaya çıkardığı tepkileri anlatır ve "Karaman-ili" beyinin düşmanlık gösterdiğini söylemekle yetinir. Karaman Beyi’ne yönelen Murad onunla ceng eder, kimseden yardım almaz, Karaman çerisinden Varsak, Tatar, Türkmen'den sayısız insan toprağa düşer, kılıçtan kurtulan Karamanlılar kaçar. Murad da çerisini alıp Bursảya döner. ${ }^{17}$ Dönemin bir başka devlet adamı ve tarihçisi Karamanî Mehmed Paşa ise kısaca onun Karamanlılarla savaştı̆̆ını her nereye yönelse galip geldiğini ifade ederek hiçbir ayrıntıya girmez. ${ }^{18}$

Hicri 824 (1421) tarihli olup Çelebi Sultan Mehmed'e sunulduğu ileri sürülen tarihî Takvim'lerden birinde, Murad'ın Kütahya, Germiyan ve Hamid'i alması hicri 780'e (1378-79); hemen ardından Karaman Beyi Alaeddin'in onun tarafindan bozguna uğratılması, barış yapılması ve Beyşehri'nin alınması 787 (1385) yılına tarihlenir. ${ }^{19} 835$ (1431-32) tarihli Takvim'de ise Murad'ın Konya'yı kuşattığı haberi vardır, savaştan söz edilmemektedir, herhangi bir tarih de verilmemektedir. ${ }^{20} 843$ (1439-40) tarihli Takvim, savaştan hiç bahsetmez. Bununla beraber Hicri 858 (1454) yılına ait Takvim'de biraz ayrıntı vardır. Burada I. Murad'ın Alaeddin üzerine yürüyerek Konya’yı kuşatıp Karaman Beyi'yle anlaştığı ve

Karaman ülkesine girmiştir. Kadı Burhaneddin belki de Osmanlılarla burada karşılaşmak istemediği için geri dönmüştür. Bezm ü Rezm'de ona söyletilen şu sözler ilginçtir: "Osmanoğlu Karaman ülkesine gelip oranın yakıp yıkımıyla meşgul, biz oraya hareket ederken kendi gücümüze güvendik, başkasından destek almadan onunla savaşalım dedik. Fakat onların karşısına güçlü bir düşman ve üstün bir hasım dikilmiştir. Bu durumda onlara saldırıp öç almak çirkin bir hareket olur, böyle bir hareket şerefimiz üzerinde kara leke gibi kalır”. Yaşar Yücel ise Kadı Burhaneddin’in kendisi için kazançlı olabilecek seferden vazgeçmesini Karamanoğlu'nu daha fazla yıpratarak I. Murad'ın Karaman ülkesine tamamen hakim olmasını kolaylaştırmak istememesine bağlar. Kadı Burhaneddin'in Karamanoğlu ile anlaşmasını, Osmanlı seferi sırasında olmuş gösterir ve Samagar, Caygazan gibi Moğol boylarının Karaman ordusunda yer almalarını buna delil olarak serd eder (Kadı Burhaneddin Ahmed ve Devleti, 1344-1398, Ankara 1970, s. 82-83).

17 “Behcetü't-tevârih", Osmanlı Tarihleri, s. 55.

18 Osmanl Tarihleri, s. 347.

19 Osmanlı Tarihine Ait Takvimler, Atsız neşri, İstanbul 1961, s. 26-27, 55; krş. Osman Turan, İstanbul'un Fethinden Önce Yazılmış Tarihi Takvimler, Ankara 1984, s. 19, 55.

20 Osmanl Tarihine Ait Takvimler, s. 69. 
Beyşehri'ni aldığı tarih, 778 (1376-77) olarak verilmiştir. ${ }^{21}$ Ruhî̀ye atfedilen Oxford Anonimi'nde ise Neşrî ve Âşıkpaşazâde hatta Oruç ekolünden ayrı bir çizgiyi izlemek mümkün görünür. Burada Neşrî ve İbn Kemal kadar olmasa bile Murad'ın Karaman seferi hakkında ayrıntılı sayılabilecek bilgiler mevcuttur. Niş hadisesi anlatıldıktan sonra Karaman seferine geçilir. Aslında Neşrî̀nin eserinde de Niş bahsi, sıra itibarıyla doğru yerde bulunur.

Şimdi bu kısa tahlillerden sonra, elimizde Frenkyazısı Savaşı'yla alakalı, olayı en ayrıntılı anlatan beş Osmanlı kaynağı ve ayrıca geç tarihli olmakla birlikte Karamanlılar zaviyesinden konuyu nakleden Şikârî̀nin eseri kalmış görünmektedir. Bunlara bir ölçüde Münşeat içinde yer alan ve bu savaşın sebepleriyle kısaca oluşumunu bildiren I. Murad'ın beşaret-nâmesi de eklenebilir. ${ }^{22}$ Kaynaklar içinde Neşrî ve İbn Kemal, diğer eserlerden ayrılarak muhtemelen bu olaylara şahit olmuş biri tarafından kaleme alınmış, ancak bugüne ulaşmamış bir başka metni aktarmaktadır. Aynı şekilde eseri geniş ölçüde Hoca Sadeddin tarafından esas alınan İdris-i Bitlisî de yine Neşrîdeki metinden ziyade İbn Kemal'in aktarımına daha yakın olarak bu ana metni kullanmıştır. Bu kaynağın Ahmedînin kayıp durumdaki Gazanâme adlı eseri olup olmadığı konusu henüz kesinlik kazanmış değildir. ${ }^{23}$ Ekte aynen tercümesini verdiğimiz beşaret-nâme metni ise çağının dilini ve üslubunu aşan bir mahiyet arz etmekte ayrıca Yıldırım Bayezid'i ön plana çıkarıp I. Kosova savaşı sonrası idam edilen kardeşi Yakup Çelebi'nin adını hiç zikretmeyerek şüpheleri üzerinde toplamaktadır. Her şeye rağmen buradaki metnin sonradan "ayıklanarak süslenmiş" olsa bile ana zeminde doğru sayılabilecek bir anlatım gösterdiği düşünülebilir. Üstelik bu beşaret-nâmeye muhatabından gelen cevapta da tarihî anlatım hatası yoktur. ${ }^{24}$ Muhtasar olan bu beşaret-nâmeyi aşağıdaki değerlendirmede diğer bilgilerle yer yer karşılaşıırarak kullanmayı tercih ettik.

21 Atsız, "Hicri 858 Yılına Ait Takvim”, Selçuklu Araştırmaları, 4 (1975), s. 261.

22 I. Murad'ın Ahmed Celayir'e yolladığı Farsça beşaret-nâme metni içinde savaş tarihi 25 Şevval 788/ 19 Kasım 1386 şeklinde verilir ve tarihi kaynaklara uygundur (I, 110-112; I. Beldiceanu-Steinherr, aynı eser, s. 237-240).

23 H. İnalcık, bu kısmın Gazanâme’den nakledildiğini yazar: Kuruluş Dönemi Osmanlı Sultanları (1302-1481), İstanbul 2010, s. 99. Ona göre bu gazanâme 1386-1389 yılları arasını kapsamaktadır. Ahmedî ve bu gazanâme hakkındaki daha detaylı bilgi için bk. H. İnalcık, Has-bağģede Ayş u Tarab: Nedimler Şâirler Mutribler, İstanbul 2011, s. 88-104.

24 Ahmed Celayir'in cevabında, Murad'ın kendi ülkesindeki durumu sorması üzerine, iç olaylardan bahsetmesi mektuplaşmanın varit olma ihtimalini güçlendirmektedir: Münşeat, I, 112-113. 


\section{Neşrî̀nin Kaynağında Frenkyazısı Savaşı ve Diğer Anlatımlar}

Öncelikle savaşı daha ayrıntılı nakleden beş Osmanlı kaynağından ilk olarak Oxford Anonimini ele alırsak, buradaki ilgili metnin Neşrî̀nin yer verdiği savaş ile ilgili kısmın kötü sayılabilecek bir özeti olduğunu görürüz. Fakat bazı yerlerde farklılıklar da yok değildir. Seferin sebebi, I. Murad Bursa'da iken Karamanoğlu'nun düşman olduğuna ve bazı yerleri vurduğu haberinin gelmesine bağlanır. I. Murad hemen asker toplamaya girişir, yeni veziri Ali Paşa ile müşavere eder, askeriyle Kütahya’ya gelir. Orada iken Karaman'ın elçisi barış teklif eder, fakat padişah razı gelmez, çünkü elçi ona bazı yersiz, ileri geri sözler (mühmelat) söylemiş ve I. Murad'ı kızdırmıştır. Bunun ardından I. Murad askeriyle Karaman toprağına girer. Murad'ın barışmadığını elçisinden haber alan Karamanoğlu da derhal asker toplar; iki taraf Frenkyazısı denilen yerde karşılaşır. Burada bir meydan savaşı yapılır. Murad'ın ordusu merkez, sağ kol ve sol kol olarak düzenlenmiştir. Anonim bu noktada savaşın tafsilatına yer vermez. Süslü cümlelerle galibiyetten söz eder. Murad Konya'ya gelir, ordusundaki "Laz kâfiri" Konya halkına çok "fesat" eder, Konya halkı aman diler, Karamanoğlu da elçiler yollar. Zira Karamanoğlu'nun hanımı I. Murad'ın kızıdır, babasına elçi olarak gönderilmiştir. I. Murad damadı adına kızı tarafından dile getirilen özürleri kabul eder. Ertesi günü Alaeddin Bey hisardan çıkıp Murad'ın elini öper sulh yapılır. Padişah askeriyle çekilir ve Beyşehri üzerine gelir, orayı alır. Sonra Bursa'ya döner. Bu bahiste Biga'nın, bu hadisenin vuku bulduğu yıl olan 766 (1364-65)'da; Kütahya'nın, bazı Germiyan kalelerinin, Hamid-ili'nin ve Beyşehri'nin 783'de (1383); Zağra, Serez ve Karaferye'nin 787'de (1385) Osmanlı eline geçtiği de belirtilir. Ancak bu bahiste olayların kronolojik sıra dahilinde yerleştirilip birbirine bağlanmasında şekli bir hata yapıldığı, bundan dolayı tarih kayıtlarında bir takdim tehir olduğu veya Karaman seferi anlatımı bittiği için geriye dönülerek diğer olayların özetlendiği yahut bu hadisenin araya sonradan eklendiği söylenebilir. Yani Oxford Anonimi kronolojik olarak olayları karışık vermiştir. ${ }^{25}$

25 Y. Yücel-H. E. Cengiz, "Ruhi Tarihi-Oxford Nüshası", Belgeler, XIV/18 (1992), 388-89. Bu bahsin sonunda: "Hem o yzl Biga feth olundu yedi yüz altmıs altıncı yzlda Kütahya ve ba’zı kıla-i Germiyan ve vilâyet-i Hamid ve Beyşehri feth oldu yedi yüz seksen üçüncü yılda Zağra ve Siroz ve Karaverye nevahileri birle feth oldu..." şeklindeki ibarelerde tarihlerin önceki mi yoksa sonraki hadiseye mi ait olduğu karıştırılabilir. Ancak Neşrî̀nin tarihi takip edildiğinde bunların sonrasına ait olduğu ortaya çıkar (krş. Cihannümâ, nşr. N. Öztürk, İstanbul 2013, s. 85, 89, 91). 
Oxford Anonimi ne benzer şekilde olayı ayrıntılarına pek girmeyerek veren Behiştî, metnini âdetâ bir "edebî gösteri" haline sokmuş, hadiseyi "münşiâne" ifadelere kurban etmiş görünür. Behiştî büyük ihtimalle bir Anonim’in metnini esas alıp olayı tasvir ederken "şahnâme" tarzında son derece süslü bir dil kullanmış ve metnini kendine ait şiirlerle bezeli halde takdim etmiştir. Süslü ifadeler çıkarıldıktan sonra olay temelli olarak geriye kalan bilgiler ise hayli muhtasardır: Karamanoğlu'nun Osmanlılara Hamidoğulları'ndan intikal eden topraklara saldırması, Osmanlı ordusunun Kütahya'da toplanması, gelen elçilere verilen cevaplar, Konya'ya yakın bir "yazı”da iki ordunun karşı karşıya gelmesi, Yıldırım Bayezid'in başarısı, Timurtaş่ın Karamanoğlu Alaeddin Ali Bey’i bozguna uğratması, on iki gün süren Konya kuşatması ve sonunda iki tarafın anlaşması fazla ayrıntıya girilmeksizin verilir, savaş tasviri şiirler eklenerek süslü ifadelerle yapılır, orduların tertibi ve savaşın cereyan tarzı üzerinde pek durulmaz. ${ }^{26}$

Oxford Anonimìnin bu itinasız özetine, Behiştîn nin edebî kaygıları öne alan metnine karşlık diğer üç metin yani Neşrî ile İdris-i Bitlisî ve İbn Kemal'in yazdıkları hayli önemlidir. Bunlar içinde de eserini daha sonra kaleme aldığı bilinen İdris-i Bitlisî ile İbn Kemal'in Neşrî̀nin metnini görmüş olma ihtimali yüksektir. Nitekim İbn Kemal'e sipariş edilmeden biraz önce Farsça bir Osmanlı tarihi kaleme alan İdris-i Bitlisînnin ana kaynakları içinde Neşrînin Cihannüma’sının da bulunduğu bilinmektedir. ${ }^{27}$ Bununla beraber İdris-i Bitlisînin süslü cümleleri altında yatan ana metin Neşrî̀deki anlatıma göre hayli muhtasar kalmıştır. Heşt Bihişt i de görmüş olarak İbn Kemal'in, Neşrînnin ayrıntılı bilgilerini kendine has üslubuyla eserine dahil etmiş olması kuvvetle muhtemeldir. Fakat Frenkyazısı Savaşı anlatımı için Neşrî̀nin metniyle yapılan karşılaştırmada daha muhtasar olarak hadiseyi nakleden İdris-i Bitlisî ve İbn Kemal'in, olayları doğrudan ondan almak yerine bizzat Neşrî̀nin kaynağını kendilerine göre uyarlamış olmaları da mümkündür. Yani her üç tarihçi de ortak bir metni kendi tarzlarına uygun olarak eserlerinde kullanmışlardır. Metinlerde hadisenin nakli itibarıyla fazlalıklar veya

26 Tarih-i Âl-i Osman, Şevket Rado yazmaları, nr. 293, vr. 180b-188b. Burada savaşın tarihi olarak sehven 780/1378-79 yılı verilir. Ancak bunun bir istinsah hatası olma ihtimalini de gözden uzak tutmamak lazımdır.

27 İdris-i Bitlisî 1506 'da eserinin ilk versiyonunun takdim ederken İbn Kemal eserini 1511'de II. Bayezid'e sunmuştu. İdris-i Bitlisî̀nin kaynakları için bk. Vural Genç, Acem'den Rum'a: Idris-i Bitlisînin Hayatı, Tarihçiliği ve Heşt Behişṫin II. Bayezid Kısmı (1481-1512), İ.Ü. Sosyal Bilimler Enstitüsü doktora tezi, İstanbul 2014, s. 409. İbn Kemal'in Neşrî̀yi daha çok kullandığı konusu, kaynakları ve İdris-i Bitlisînnin eseriyle mukayesesi için bk. Genç, Acem'den Rum'a, s. 462-466. 
ayrıntılarda küçük farklılıklar yok değildir. İdris-i Bitlisî ve İbn Kemal'in süslü anlatımı karşısında Neşrî daha sade sayılabilecek bir ifadeyle metni aktarmış görünmektedir. Kısaca İdris-i Bitlisî ile İbn Kemal'in Neşrînnin metnini görmüş olma ihtimalleri yüksekse de onların tercihinin buradaki metin değil orijinal kaynağın bizatihi kendisi olduğu istidlal edilmektedir.

Bu meyanda önce Neşrî̀nin naklettiği metni ele almak icab etmektedir: ${ }^{28}$ Burada öncelikle I. Murad'ın Niş ve etrafındaki kaleleri alıp Sırplarla sulh yaptıktan sonra Edirne'ye döndüğü ve Karamanoğlu İbrahim Bey’in Osmanlı topraklarına saldırdığı haberinin geldiği, bunun üzerine hemen Bursàya gittiği belirtilir. O sırada Bursa'da bulunan Mısır/Memlük elçisiyle görüşen I. Murad 788 (1386) baharında Karaman-ili'ne sefer düzenlemeye karar verir. ${ }^{29}$ Karamanoğlu bunu işitince hemen Tatar, Türkmen, Varsak, Turgut, Bayburt'tan leşker devşirir. Tatar/ Moğol ulusu beyi Teberrük, Samagaroğlu Hızır, Barambay, Cağazan, Suga/sonra Tula, Tosboğa gibi diğer Tatar beyleri de onun yanına gelmiştir. Sonra Alaeddin Bey bununla da kalmaz ve I. Murad'a elçi yollar, elçinin sarf ettiği tehditkâr cümlelere karşı Murad hayli sinirlenir. Gece gündüz gaza ile meşgul olduğunu, kendisi gazada iken Karamanoğlu’nun Müslümanları incittiğini, "ahd u amana" sâdık biri olmadığını, gazaya mani olduğu için üzerine yapılacak seferin meşru bulunduğunu, savaşa hazırlanması gerektiğini belirtir. Haberi alan Karamanoğlu bunun üzerine hemen beyleri teker teker çağırır onlara durumu bildirir. Samagaroğlu Hızır, Teberrük, Babukoğlu Ali, Dilencioğlu Pir Ali yer öpüp yanında olduklarını söylerler. Böylece ittifakı sağlam hale getirirler. ${ }^{30}$

28 Neşrî̀nin eserindeki bu bahis için bk. Cihannüma, s. 91-100.

29 Savaşın tarihi konusunda tereddüt olduğunu da ifade etmeliyim. Savaşın tarihini Münşeat'ta yer alan beşaret-nâme 25 Şevval 788/ 19 Kasım 1386 Çarşamba günü olarak gösterir (tarih çevrildiğinde bu gün çarşamba değil pazartesiye denk düşer. Çarşamba olduğunda 21 Kasım tarihini esas almak gerekecektir). Fakat bu sırada Osmanlı ordusunda vezir olarak Çandarlı Ali Paşa’nın adı geçer. Çandarlı Ali Paşa’nın vezir oluşu babasının 1387'deki vefatı üzerinedir. Tartışmalı olan Niş'in fethi tarihiyle bunu birleştirenler savaşın 1386'ya değil 1387'ye tarihlenmesinin doğru olacağını düşünürler: Tarihle ilgili ilk tartışma için bk. İ.H. Uzunçarşılı, Osmanlı Tarihi, Ankara 1995, I, 249; Beldiceanu-Steinherr, aynı eser, s. 237-238. Savaşın 1386-87 kışına doğru gerçekleşmesi mümkün görünür. Zira Murad Karaman bölgesinde savaştan sonra bir süre kalmıştır. Neşrî ve özellikle Şikârî̀nin anlatımı bunu açık şekilde ortaya koyar. 1387'de kış vakti bu bölgeden ayrılmış olması makul gözükür. Münşeat'taki tarihi Murad'ın bölgede bulunduğu zaman itibarılla değerlendirmek mümkündür. Bu mektuba Ahmed Celayir'den gelen cevabın tarihi ise 790 senesinin Rebiülevvel ayı başına ( 10-20 Mart 1388) denk düşer. Bu durum 1387 senesi başları ile ilgili tahminleri güçlendirir. 
Murad Kütahya’ya geldiğinde Karamanoğlu'ndan yeni bir elçi ulaşır ve barışmak isteğini iletir. Fakat bu defa Murad daha önce kendisini tahkir ve tehdid ettiği için artık vaktin geç olduğunu, asker topladığını, savaşın kaçınılmaz bulunduğunu, zaten Karamanoğlu'nun sürekli ahdini bozduğunu, gazaya giderken arkadan onu vurduğunu söyler: "ben gazaya mesgulken il urup Müslümanlart incitmiştir. Ben anın gibi varıp ilden at ve eşek ve dana tulpu sürmezem, gelsin uğraşalım, hiç arada yoksula ziyan gelmesin". Bu sözlere karşı Karaman elçisi askerlerinin savaş için yeterli bulunduğunu, barış taleplerindeki asıl amacının arada kalacakların zarar görmemesi olduğunu, aslında kendi askerinin onlardan aşağı olmadığını dövüşe hazır bulunduklarını yüksek perdeden ifade edince I. Murad çok kızar. Yine gazaya mani olma noktasında onları suçlar, bu yüzden o yıl gazadan kalındığı, bari hazır böyle iken Karamanoğlu’nun "şerrini gidereceğini” belirtip elçiyi huzurundan kovar. ${ }^{31}$ Hemen sonra üç merhalede Karahisar'a gelir. Burada birkaç gün oturur ve veziri Ali Paşa gelip onunla burada buluşur. ${ }^{32}$

Karaman elçisi gelip durumu beyine haber verir. Karamanoğlu’na yönelik I. Murad'ın sarf ettiği, dana ve buzağıyı kovmaktan başka artık elinden iş gelmez şeklindeki sözlerinden kastın Alaeddin Bey'i ortadan kaldırıp Konya ve Larende’yi almak olduğu kanaatine varılır. Alaeddin Bey hemen Turgud, Tatar ve Türkmen'e haber salar, I. Murad'ın amacının Larende'yi zabt etmek olduğunu, bunun yerine kendilerinin karşı atağa geçip Bursa'yı hedef almaları gerektiğini bildirir. Elçiye Osmanlı askerinin sayısını sorar, 70.000 kişi olduğunu öğrenince kendi askerinin ondan fazla olduğuna kanaat getirip rahatlar.

31 Cihannüma, s. 94; benzeri ifadeler için krş. Heşt Bihişt, Nuruosmaniye Ktp., nr. 3209, 151a-b.

32 Ali Paşa, babası Çandarlı Halil Paşa'nın Serez'de vefatının ardından gelerek orduya katılmıştır: İ.H. Uzunçarşılı, Çandarlı Vezir Ailesi, Ankara 1974, s. 31. Çandarlı Halil Paşa'nın vefat tarihiyle ilgili ona ait mezar taşı kitabesinde yer alan kayıtlar problemli gözükür. Tahribata uğramış kitabedeki Farsça atılan tarihin 789/1387 olduğu görüşü hakimdir. Fakat bu durum Neşrî̀nin verdiği Karaman seferi tarihiyle uyuşmaz. Üstelik Neşrînnin kaynağı savaş sırasında Osmanlı birliklerinin nizamını belirtirken, Murad ile buluştuğunu belirttiği Ali Paşa'nın adından bir daha hiç bahsetmez. Bu durum Murad ile buluştuğu halde Ali Paşa’nın savaşta bulunup bulunmadığı konusunda tereddüde yol açar. Yukarıda 27. dipnotta tartıştığımız savaşın tarihi açısından bu kitabenin belirleyici olduğu görüşü ortaya atılmıştır. Hatta S. Reinhart, bu savaş için Niş' in fethini 1386 bahar veya yaz aylarına çekerek daha sonraki gelişmeler tahtında 1387 bahar veya yaz aylarını teklif eder: "Niş่ten Kosova'ya: I. Murad'ın Son Yıllarına İlişkin Düşünceler”, Osmanlı Beyliği (1300-1389), ed. E. Zachariadou, İstanbul 1997, s. 194-195. Fakat bunun biraz daha geriye çekilmesi gerektiğini düşünmekteyim (bk. 29. not). 
Neşrînnin kaynağı bu hususları dile getirdikten sonra meydan savaşının nasıl cereyan ettiğini anlatmaya başlar. Buradaki münderecat her şeyden önce bir Osmanlı kroniğindeki ilk büyük meydan muharebesinin tafsilatlı bilgilerini ihtiva etmesi bakımından son derece önemlidir. Bu kısım doğrudan savaşa şahit olmuş birinin nakline veya savaş sonrası hazırlanmış bir zafer-nâme metnine benzer. Önce Neşrî̀nin kaynağında savaşın nasıl vuku bulduğuna göz atalım: Kaynakta savaşın anlatımı üç başlık halinde sıralanmıştır. İlk başlıkta "tertîb-i asker-i Gazi Murad Han" denilerek Osmanlı ordusunun düzeni ve savaş tertibi verilmiştir ki bu daha önce kaynaklarda hiç rastlanmayan bir şekil özelliği gösterir. İkinci başlıkta ise "tertîb-i cüyûş-ı Karaman" denilerek önce Karaman birliklerinin düzeni, ardından da savaşın cereyan şekli aktarılmıştır. Üçüncü başlık savaşın sonunda Murad'ın Konya'yı muhasara etmesi dolayısıyla "muhasara-i Konya" şeklinde verilmiştir. Kısaca buradaki metin Osmanlı kroniklerindeki ilk müstakil ve mufassal meydan savaşı anlatımı olmak dolayısıyla ayrı bir hususiyeti haiz görünür.

Neşrî̀nin kaynağının anlatımına göre, I. Murad ordusuyla Konya yakınlarında bulunduğu anlaşılan Frenkyazısı adlı düz araziye kondu. ${ }^{33}$ Karamanoğlu da bir konak kadar uzaktaydı. O gece iki tarafın çerisi de öncü birlikler (talia ve karavul) çıkarttı, birbirini sabaha kadar gözledi. Sabah olunca ordular karşılıklı olarak tertip aldı. Osmanlı ordusunun düzeni şu şekilde idi:

1) Murad kendi adamlarıyla ortada durdu. Yaya askerini önüne, atlıları geriye koydu. Böylece merkezî ana güç oluşturulmuş oluyordu.

2) Büyük oğlu Bayezid sol cenahta, Firuz Bey, Hoca Bey ve Kastamonu askeriyle duruyordu, onların yanında Murad'ın vasali olarak orduya çağrılmış Laz/Sırp askerleri de vardı. Bunlar bu kolun ucunda yer aldı.

3) Sağ kolda küçük oğlu Yakup Çelebi ile Karesi beyi Eyne Subaşı, ${ }^{34}$ Eğridir subaşısı Kutlu Bey, ${ }^{35}$ yine Murad'ın Rumeli yakasındaki vasalleri "Sarac"

33 Burası III. Haçlı seferi sırasında Konya'ya giren (1190) Haçlı birliklerinin toplandıkları yeri ifade etmek üzere bu adı almış ve hatırası da uzun süre devam etmiş olmalıdır.

34 Kendisi daha sonra Kosova savaşına da katılacaktır: Neşrî, Cihannüma, s. 122.

35 Cihannüma'nın F. R. Unat-M. A. Köymen neşrinde (Kitâb-ı Cihannüma, Ankara 1987, I, 225-227) "Eğridir subaşısını Kutlu Bey’le sağ cenah edinip” tarzında geçen ibare ilk versiyonu izleyen nüshalarda "Eğridir subaşısı Kutlu Bey” tarzındadır (N. Öztürk neşri, s. 97-98). Unat-Köymen neşrinde muhtemelen bir fazlalık vardır, fakat bu durum anlamı hayli etkileyecek derecede önemlidir. Zira Eğridir’in fethini Esterâbâdî Frenkyazısı Savaşı sonrasına koyar (Bezm ü Rezm, s. 293). Ama bu sırada Eğridir’in 
ile "Köstendil" bulunuyordu. Bu hıristiyan birlikleri yine bu kolun ucunda yerleşti.

4) Leşker sürücü Kara Timurtaş, Germiyan askeriyle ortada, göğüste durdu.

5) Ahmed Çavuş ile Sivrihisar subaşısı Timurtaş ise askerin ardında yerleşti.

6) Yayabaşıları Saruca Paşa, ${ }^{36}$ İncecik Balaban, Tovuca Balaban, İlyas Bey ve Müstecab Subaşş ${ }^{37}$ da yaya askerleriyle sağ ve sol kollara dağıtıldı.

Bu ordu tertibine bakıldığında öncelikle I. Murad'ın bizzat durduğu merkezde kendine has yaya birliklerinin bulunduğu ve bu merkezin diğer sağ-sol kollarının bunları takviye eden yayalarla çevrildiği hemen anlaşılır. Yaya birliklerinin ordunun ana güçleri içinde önemli bir yer edinmiş olduğunu bu düzen açık şekilde gösterir. Bununla beraber Celayirli Ahmed'e gönderilen beşaret-nâme metninde Timurtaş Paşa Rumeli emirülümerası, Saruca Paşa ise Anadolu beylerbeyi olarak belirtilir. Üstelik Yakub Çelebi'den hiç söz edilmez, Yıldırım Bayezid'in adı öne çıkarılır. ${ }^{38}$ Fakat bu bilgiler Neşrînin yukarıda sıraladığımız ordu düzeni ile ilgili listesiyle çelişir gibidir; burada resmî mektubun dilinin gerçek anlatıma galip gelme ihtimali hatıra gelir. Resmî anlatım bu farklılığı daha şeklî hale getirmiş olmalıdır. Aslında Hem Saruca ve hem de Timurtaş Paşa’nın adları her iki metinde de belirtilir. Fakat henüz klasik anlamda Rumeli ve Anadolu beylerbeyi terimlerinin oluşmadığı göz önüne alınırsa, Neşrînnin metindeki bu paşaların görevleriyle ilgili tanımlamaların orijinal metne dayandığı ve doğru olarak kendi döneminin unvanlarını gösterdiği hemen fark edilir. Münşeat'daki mektubun ise bu anlamda görev tanımlamalarını bilinen unvanlara dönüştürdüğü söylenebilir.

Ordunun diziliminde Şehzade Bayezid kolunda Kastamonu askerlerinin yer alması, vasallik bağlarıyla alakalı olmalıdır. Bu koldaki beylerden Firuz Bey Ankara emiridir ve I. Murad'ın Rumeli'ye geçtiğinde Anadolu muhafazasında bulunan beş beyden biri olacaktır. Hoca Bey de Akşehir subaşılığı görevine getirilecektir. Sağ koldaki Şehzade Yakub Çelebi’nin yanındaki Kutlu Bey Eğridir subaşısıdır. Bu tertibe dikkat edildiğinde Osmanlı birlikleri içinde Germiyan,

Osmanlı kontrolü altında olduğu açıktır. Belki I. Murad kendisine tabi olan Eğridir’i savaş sonrası Karamanlılar'dan geri almıştır.

36 Daha sonra Kosova savaşı arifesinde kendisinden "Rumeli yayabaşısı Ulu Bey Subaşı ki Saruca Paşa demekle maruf” diye bahsedilir: Neşrî, Cihannüma, s. 103.

37 Kosova savaşı sırasında kendisinden "sekbanbaşı” olarak söz edilir: Neşrî, Cihannüma, s. 103.

38 Münşeat, I, 108-110. 
Candar ve Hamidoğulları'na ait askerlerin mevcut bulunduğu anlaşılır. Germiyan birlikleriyle orta hatta duran Kara Timurtaş Paşa Kütahya, Uşaklı, Sandıklı bölgelerinin idarecisidir. Diğer Timurtaş ise Sivrihisar ve Sakarya hattının emiri durumundadır. ${ }^{39}$ Öte yandan I. Murad'ın Sırp vasallerinin hem sağ hem de sol kolun ileri "ucunda" yani en son kısmında yer almış olmaları dikkat çekicidir. Sırp birlikleri 1371'den sonra Osmanlı vasali haline gelen Lazar'ın yolladığı kuvvetler olmalıdır. Ayrıca savaşa yine I. Murad'ın vasali olan Konstantin Dejanovic (Köstendin/Köstendil), Marko Kralyevic'in ve "Sarac" diye Osmanlı kroniklerinde adı geçen Vidin prensi Stratsimir’ in (Sracimir) askerlerinin katıldığı istidlal edilmektedir. ${ }^{40}$

Burada verilen bilgiler bir ölçüde yeni bir sistemin ortaya çıktığının ilk habercisidir. Gerçi Osmanlı ordusunun merkezi ve bunun sağ ve sol kolları ile alışılmış/bilinen bir tertibi hemen fark edilir, ancak buna bağlı olarak ayrıca bir ön grubun daha oluşturulduğu görülür. Bu ön grupta Kara Timurtaş Paşa’nın birlikleri vardır. Bu kısmın sağ ve sol cihetleri yaya güçlerince takviye edilmiştir. Bu durumda yayaların öncü kuvvetler şeklinde yerleştirilmiş olduğu ortaya çıkar. Ancak bu düzen klasik anlamda daha sonra görülecek olan kuvvetli bir merkez ve iki kanatta atılıarın yer aldığı bir sistemi çağrıştırmamaktadır. Ordunun tertibindeki bu biraz da karışı gibi görünen durum sonradan metni kullanan bazı tarihçiler tarafından muhtemelen kendi dönemlerindeki gelişmiş tertibe uygun bir tarzda anlatılmış, Rumeli ve Anadolu askerlerinin sağ ve sol koldaki yerleşme nizamları esası içinde kurgu yapılmıştır. Münşeat taki beşaret-nâme metni yanında aşağıda zikredilecek olan İbn Kemal'in ordu düzeniyle ilgili anlatımı bu kurguya güzel bir örnek oluşturur.

39 Neşrî, Cihannüma, s. 105. Bu sırada vezir Şahin Lala'nın vefatı üzerine beylerbeyiliğinin (Rumeli) Kara Timurtaş'a verildiği kaydının (Cihannüma, s. 102) ardından bu defa Kütahya merkezli bölgenin idarecisi olarak da onun gösterilmesi dikkat çeker. Burada bir tenakuz veya takdim-tehir söz konusudur. Timurtaş Paşa için ayrıca bk. F. M. Emecen, "Timurtaş Paşa, Kara”, DİA, XLI, s. 185-186.

40 Sırp despotu Lazar’ın Karaman seferi arifesinde ve sonrasında Osmanlı vasali olmadığı ve Neşrî̀nin burada bir kurgu yaptığı görüşü için bk. S. Reinhart, "Niş'ten Kosova’ya”, s. 224-225. Ancak bu metin Reinhart'ın ifade ettiği gibi Neşrî tarafından kurgulanmış değildir. Neşrî̀nin döneme şahit olan kaynağından yansımaktadır. Bu bakımdan bu bilgileri karışık kronolojik argümanlara kurban etmemek gerekir. Stratsimir için bk. A. Kuzev, "Die Beziehungen des Königs von Vidin Ivan Sracimir zu den osmanischen Herrschern”, Etudes balkaniques, III (1971), s. 121-124. Sarac'ın Dobruca bölgesi Tatarları'nın başı olduğu da ileri sürülür. 
Neşrî̀nin müdahale etmeden aktardığı kaynağındaki “orijinal” ordu tertibi, bir Osmanlı kroniğindeki ilk mufassal bilgi olma özelliği taşımaktadır. Bunu daha sonra 1389'daki I. Kosova savaşı takip edecektir. Burada bir parantez açarak 1329'daki Pelekanon ve 1371'deki Çirmen savaşlarıyla alakalı Osmanlı kaynaklarında çok az ya da hiç bilgi bulunmadığını hatırlatmalıyız. Böyle olunca Frenkyazısı Savaşı'nın Osmanlı kaynakları temelli olarak genişş şekilde nakledilen ilk muharebe olduğu açık şekilde ortaya çıkar.

Metinde her iki tarafin asker mevcudu konusunda sadece 70.000 rakamı geçer. Kaynağa göre bu rakam Osmanlı tarafına aittir, Karamanoğlu ise bundan daha fazla askeri güce sahip olduğu kanaatindedir. Bununla birlikte ordu mevcutlarının 20.000'i geçme ihtimali hiç yoktur. Rumeli yakasından Osmanlılar ancak 2000 civarında vasal güçleri getirebilmişlerdir. Bu rakam nispeten de olsa asker sayısı açısından bir fikir verir. İki taraf birbirine yakın askeri güçlerle karşı karşıya gelmiş olmalıdır. Bununla beraber asker sayısının o dönemler için önemli rakamlara tekabül ettiği düşünülebilir.

Neşrî̀nin kaynağı Karaman birliklerinin düzenine ikinci başlıkta yer verirken bunların Tatar, Türk, Varsak, Turgud, Bayburt'un atlı birlikleri olduğunu "koşun koşun” geldiklerini bildirir. Alaeddin Bey ortada durmuştur. Samagar, Cağazan, Barambay, Tula (ve Suga ), solda yerleşmiştir. Türk/Türkmen atlıları sola kuvvetlerinin kanadında bulunmaktadır. Ahi Teberrük ve Savcı Ağa sağda durmuştur, Varsaklar da bunların kanadında yer almıstır. Buradaki anlatımda Karamanlıların tamamının atlılardan oluştuğu izlenimi edinilir. Atlı birliklerin grup grup belirli bir düzen içinde Osmanlı ordusuna karşı yürüyüşe geçtiği de anlaşılır. Karaman ordusunun yelpaze şeklinde ortada Alaeddin Bey olduğu halde Osmanlı ordusuyla karşı karşıya geldiği açıktır. Fakat bu basit düzendeki atlı birliklerin görünüşüyle Osmanlı ordusunun durumu karşılaşııııldığında, Osmanlı tarafının hayli farklı ve daha sofistike denilecek tarzda bir şekle sahip olduğu hemen fark edilir. Atlı birlikleri ilk karşılayacak ve durduracak olan Osmanlı yaya birlikleri olacaktır. Çağdaş Bizans kaynağı Kantakuzenos’un beyanları çerçevesinde söz konusu değişimin ilk emarelerinin Orhan Bey döneminde 1329'daki Pelekanon savaşında ortaya çıktığı tesbit edilmiştir. ${ }^{41}$ Şimdi Frenkyazısı Savaşı'yla açık şekilde bu tertibin tam anlamıyla yerleşmiş olduğu söylenebilir.

41 Pelekanon savaşı için bk. F. M. Emecen, "İlk Osmanlı Savaşları ve Taktikleri”, Osmanlı Klasik Çă̆ı̆ıda Savaş, İstanbul 2015, s. 15-25. 
Tekrar savaşın anlatımına dönersek, saldırıya ilk geçenler Karamanlılar oldu ve sol koldaki Samagar ileri yürüdü. Onu Osmanlı tarafından ön safta ortada duran Timurtaş Paşa karşıladı. Teberrük de sağ koldan hareket etti, Tatar ve Varsaklar ok yağdırarak onu koruma atışıyla destekliyorlardı. Şehzade Bayezid bunu görünce hemen babasından izin istedi, Murad ona izni verince sol kanattaki askeriyle "ıldırım gibi” yetişti. Onun hücuma kalkışı üzerine arkasından sol kanadın ucunda yer alan Firuz Bey, Hoca Bey ve sağ koldaki Kutluca Bey, Eyne Subaşı saldırıya geçti. Ayrıca ordunun en önünde ortada yer alan Timurtaş Paşa ile art kısımda bulunan Çavuş Bey ve Sivrihisarlı Timurtaş hamle yaptı. Saruca Paşa, İlyas Bey ve Müstecab da yaya askerleriyle ileri yürüdü. Bu basit anlatıma göre Osmanlıların hücum düzeni taktik olarak bir çevirme harekatına benzemektedir. Sol koldan hücumu bu kanadın ucundaki birlikler desteklerken, hemen ardından sağ kanat birliklerinin yürüyüşü vuku bulmuş, aynı anda ortadaki birlikler de doğrudan bir yarma harekatına girişmiş olmalıdır.

Savaşın cereyanı hakkında kaynakta ayrıntı bulunmaz. Sadece büyük bir çatışmanın başladığı, Karamanlıların bu toplu ve ağır hücuma dayanamayıp dağıldıkları, önce ilk saldıran Samagar, Tula, Barambay, Cağazan, Suga, Teberrük, Kazan ve Tosboğa’nın kaçtıkları, onları Tatar ve Varsak grubunun izlediği, Karamanoğlu Alaeddin Bey’in kendi birlikleriyle yalnız kaldığı belirtilir. Ancak o da tam karşısında olan Timurtaş Paşa’nın saldırısı üzerine çekilmek zorunda kalmıştır. Ordunun ağırlıkları Osmanlı askerlerince yağma edilir. I. Murad Karamanoğlu'nun eşyalarını ve harp aletlerini Timurtaş Paşa'ya hediye eder. Anlaşılacağı üzere bu çevirme ve ortadan yarma harekatı Karaman atlı birliklerinin savrulmasına ve bir daha toparlanamamalarına yol açmış, etrafının çevrileceğinin farkına varan Alaeddin Bey ise hemen çekilerek esir düşmekten kurtulmuştur.

Kaynakta savaşın üçüncü safhası olarak Konya muhasarası gösterilir. Buna göre Alaeddin Bey kaçıp Konya kalesine kapanınca I. Murad burayı muhasara eder. Fakat kimsenin kendi emri dışında saldırmasına izin vermez. Bununla beraber Sırp çerisinden birkaç asker bu emre uymadıkları için cezalandırılır. I. Murad on iki gün surların karşısında hareketsiz durur. Karamanoğlu perişan olup elçi yolladıysa da bunu kabul etmez. Bu durum karşısında I. Murad'ın şehri ele geçirip kendisini ortadan kaldırmayı düşündüğünü zanneden Alaeddin Bey, hanımı olan Murad'ın kızı Sultan Hatun'u elçilikle yollar. Onun vasıtasıyla barışa yanaşan Murad, damadının gelip itaat arz etmesini ve elini öpmesini ister. Alaeddin Bey sabahleyin I. Murad'ın otağına gelir, “elini öpüp ayağına baş” koyar. I. Murad da yine memleketini iklimini ona bağışlar. Oradan göçüp Beyşehri alır, Antalya 
ve İstanoz’u (Korkuteli) alma niyetinden vaz geçip Bursa’ya döner. Sonra Tekeoğlu da sultanla barışmayı tercih eder. ${ }^{42}$ Neşrî̀nin kaynağının bu savaş tasvirinin genel hatlarıla doğru olma ihtimali yüksektir.

İdris-i Bitlisînnin metninde daha muhtasar olmakla ve isimler hatalı kaydedilmekle birlikte, bir-iki farklı ayrıntıyı bulmak mümkündür. Bu ayrıntılardan en önemlisi Kara Timurtaş Paşa’nın 2000 Sırp yardımcı kuvvetiyle savaşa katılmak üzere orduya ilhakı konusudur. ${ }^{43}$ Burada verilen rakam mesela onunla büyük benzerlik arzeden İbn Kemal'in eserinde mevcut değildir. İdris-i Bitlisînnin diğer anlatımları ise İbn Kemal ile nispeten paralellik gösterir, fakat daha muhtasar görünür. Mesela savaş kısmından çok az bahsedilmiş, ${ }^{44}$ ayrıntılara hiç girilmemiş, süslü üslup öne çıkarılmıştır. Burada Timurtaş Paşa tek bir şahıs olarak yer alır ve Anadolu beylerbeyi olarak tanımlanır. 2000 zırhlı Sırp askerini o getirmiştir. Kütahya sahrasına gelindiğinde gelen elçinin tavrına ve Murad'ın sözlerine temas edildikten sonra elçinin küstahça sözleri üzerine kovuluşunu geniş olarak anlatan İdris-i Bitlisî, ordu düzenine geçer. Ona göre Murad, ordunun kollarını iki oğluna Yıldırım ve Yakub Çelebi'ye vermiş kendisi yeniçeri ve batıdan gelen müttefikleri ve yakınlarıyla ortada yerleşmiştir. Sağ kanatta Yakub Çelebi'nin yanında Saruca Paşa, Balaban Bey, İlyas Bey ve Müstecab Bey olup bazı Anadolu ümerasıyla bulunmaktadır. Sol kanatta Yıldırım'ın yanında ise Firuz Bey, Kastamonulu Hoca Bey ve 2000 zırhlı Sırp birliği yer almaktadır. Kara Timurtaş Paşa kendi hassa askeri ve Rumeli ümerasıyla ordunun arkasındadır. Taktiğe göre sağ veya sol kanattan herhangi bir talep gelirse bunlar hemen o tarafa yetişmek üzere ihtiyat kuvveti durumundadır.

İdris-i Bitlisînin bu tertip ile ilgili anlatımının Neşrînnin nakliyle benzerliği olmadığını söylemek mümkündür. Zira o kendi dönemindeki düzene göre böyle bir sunuş yapmışa benzemektedir. Savaş anlatımında ise Yıldırım Bayezid'i öne çıkarması bu anakronizminin açık yansımasıdır. İdris-i Bitlisı̂ye göre, Yıldırım Bayezid'in saldırıya başlayıp üstünlük sağlamasından cesaret alan Osmanlı beyleri hemen harekete geçmiş, bunlardan biri olan Timurtaş ise Alaeddin Ali Bey'e tesadüf ederek onu bozguna uğratmıştır. Hatta bu yüzden Alaeddin Bey'in savaş meydanında kalan malları ona bağışlanmıştır. Bu noktada İdris-i Bitlisi diğer kaynaklarda bulunmayan bir bilgiye de yer vererek başarısından dolayı Timurtaş Paşảnın Rumeli beylerbeyliği ile vezirlik rütbesini aldığını ve bunun bu şekilde yapılan ilk

42 Cihannüma, s. 96-99.

43 Heşt Bihişt, vr. 151a.

44 Heşt Bihişt, vr. 151b-152a. 
tayin olduğunu belirtir. Ancak bu bilginin ana metne dayanıp dayanmadığı anlaşılamamaktadır. Üstelik Neşrînnin aktardığı metinde de böyle bir bilgi bulunmaz. Bunun İdris-i Bitlisînin şahsi yorumuna dayandığını düşünmek daha uygun olur. İdris-i Bitlisînin metni, orijinal kaynağa sadık bir temelde ilerleyen Neşrînnin anlatımına göre daha sofistike bir mahiyet arz eder. Aynı durum İbn Kemal'in eserinde de görülür. Onun anlattıklarında ise İdris-i Bitlisîye nispetle bazı ayrıntı farklılıkları mevcuttur. İbn Kemal'e geçmeden önce İdris-i Bitlisînnin Konya kuşatmasıyla ilgili verdiği bilgilerin hem Neşrî ile hem de İbn Kemal ile benzerlik gösterdiğini, ancak tek önemli farkın I. Murad'ın kızı ve Alaeddin Ali Bey'in hanımı olan Sultan Hanım’ın adının "Sabiye” olarak kaydedilmesi olduğunu belirtelim. ${ }^{45}$

Esas itibarıyla İbn Kemal'in konuyu ele alış şekli, yukarıda anlatılanlarla örtüşen bir genel çerçeveyi haizdir. ${ }^{46}$ Ancak İbn Kemal, satın alınan toprak meselesini öne çıkarmaksızın Alaeddin Bey'in fesat başı olduğunu belirtir ve onu Osmanlıları arkadan vurmakla suçlar. Savaş kararı alınınca İsfendiyaroğlu’ndan Germiyan'dan ve Las'dan (Sırplar) askerlerin geldiğini beyan eder. Karamanlıların gücünü belirtirken Turgud, Varsak, Tatar ve Türkmen gruplarını sayar, ileri gelen beyleri arasında ise Teberrük Bey, Samagaroğlu Hızır Bey, Dilencioğlu Pir Ahmed Bey ile Babukoğlu Ali Bey’i zikreder. Halbuki İdris-i Bitlisi, bu beyleri Turgudlu, Tatar ve Türkman Cemaati, Samagarlu, Bayburdlu, Eski-İllü diye vermiştir. İbn Kemal'e göre, I. Murad Karaman elçisinin sahte barış teklifini reddettikten sonra Kütahya’dan üç günde Karahisar’a gelir, oradan Konya önlerine ulaşır. Frenkyazısı'nda durur. Buraya kadar Neşrî̀deki metni takip ettiği anlaşılan İbn Kemal savaşın tasviri kısmında farklı bilgilere yer verir. Ona göre Osmanlı ordusunun sağ kolunda Yakub Çelebi, Kastamonu askeriyle İlyas Bey, Müstecib Subaşı, İnecek Balaban vardır. Sol kolda ise Bayezid Han yanında Las/Sırp askeriyle ${ }^{47}$ Firuz Bey, Hoca Bey durur. Merkezde yeniçerilerin başında "yeniçeri ağası" Saruca Paşa vardır. Kendisine bağlı yayalarıyla I. Murad'ın önünde bir "set” gibi

45 Heşt Bihişt, vr. 152b. Larende'de 1382 tarihli medresesi bulunan bu hanımın adı kitabede Sultan Hatun diye geçer. Nefise ve Melek Hanım şeklinde de anılır. Bak. dipnot 8.

46 Kemalpaşazâde (İbn Kemal), Tevârih-i Âl-i Osman, III. Defter, haz. Abdullah Satun, İstanbul 2014, s. 54-71.

47 Gerek Neşrî gerekse İbn Kemal'de rastlanmayan ilginç ayrıntı, sadece Heşt Bihişt'te ve ondan naklen Hoca Sadeddin Efendi'nin Tâcü't-tevârib'inde (I, 104) yer alır. Bu da Sırp ve Bulgar destek birliklerinin Rumeli beylerbeyisi Kara Timurtaş Paşa ile birlikte 2000 zırhlı atlı olarak savaşa gelmiş olmaları keyfiyetidir ki bundan yukarıda söz edilmişti. 
durmaktadır. Ordunun ardında ise Kara Timurtaş Paşa’nın birlikleri yer almıştır. ${ }^{48}$ İdris-i Bitlisî ile karşılaştırılacak olursa burada bazı farklılar olduğu hemen anlaşılacaktır. Mesela İdris-i Bitlisî, Hoca Bey’i Kastamonu askeriyle Yıldırım Bayezid'in yanında gösterirken İbn Kemal bunları İlyas Bey'in emrinde Yakup Çelebi kolunda zikretmiştir. Saruca Paşa konusunda da farklılıklar vardır. İdris, onu yine Yakup Çelebi kolunda gösterir, fakat İbn Kemal'e göre o yeniçerilerle birlikte merkezdedir.

Anlaşılacağı üzere bu noktaya kadar Neşrî Tarihi'nde yer alan metine kıyasen hem İdris-i Bitlisî hem de İbn Kemal daha muhtasar bir anlatımda bulunmuşlardır ve üstelik ordunun yerleşim düzenini de farklı bir şekilde vermişlerdir. Muhtemelen İbn Kemal, tıpkı İdris-i Bitlisî gibi, kendi dönemindeki ordu yerleşme nizamını, Neşrî̀de bu hususta biraz da karışık olarak verilen ayrıntılar çerçevesinde, kendisine göre yeniden düzenlemiş gözükmektedir. Ancak bunu yaparken Neşrî̀deki metinde yer alan tertibi değiştirdiği, Neşrî̀nin metninde geçmeyen "yeniçeri” lafzııı kullandığı, Timurtaş Paşảnın ordunun göğüs kısmında yer almasını ordunun ardında diye tarif ettiği, dolayısıyla istifade ettiği metni eksik bıraktığı hemen dikkati çeker. Hatta İdris-i Bitlisîde olduğu gibi Neşrînnin zikrettiği iki Timurtaş’ı tek bir şahsa indirdiği ve onu da ordunun ardına koyduğu görülür. Onun Kara Timurtaş olarak gösterdiği ve ordunun artçı birliklerinin kumandasını üstlendiğini söylediği şahıs, Neşrînnin kaynağına göre Sivrihisar subaşısı Timurtaş'tır. İbn Kemal savaşın anlatımı bahsinde hem İdris-i Bitlisî̀ye hem de Neşrînnin metnine nispetle daha fazla ayrıntı vermiştir. Ancak bu ayrıntıların Neşrî̀deki metne bağlı bir genişletme olduğu ileri sürülebilir.

İbn Kemal'e göre Karaman ordusunda Turgut ve Varsak atlıları saf saf durmuş, iki koldan yürüyüşle hücuma geçmiştir. Buna karşı da sağ ve sol koldaki Osmanlı birlikleri hareket etmiştir. Bu esnada Samagaroğlu Hızır, bir "yılan gibi" süzülüp harp alanının bir kenarından ansızın çıkmış ve doğrudan I. Murad'ın bulunduğu merkezi hedeflemiştir. Timurtaş kendi alayıyla ordunun arkasında beklemektedir, bu saldırı üzerine kendisine haber yollanarak hemen harekete geçmesi istenmiştir. $\mathrm{O}$ da bulunduğu yerden çıkıp saldıranların önünü kesmiş ve onları dağıtmıştır. Bunu gören Teberrük Bey, Tatar ve Varsak atılıları ile bir büyük yığın halinde saldırıya geçmiştir. Onun arkasından ise okçu atışlarıyla bu hücuma destek verilmiştir. Bu saldırıyı Osmanlı tarafından Şehzade Bayezid karşılamış ve durdurmayı başarmıştır. Bu sırada I. Murad'ın sağ cenahındaki askerler hemen

48 İbn Kemal, III. Defter, s. 63-64. 
savaşa iştirak etmiş, Karamanlıların sol koluna saldırıp bu cepheyi çökertmiş, Turgut atılıarı ve Türkmenleri dağıtmışır. Böylece Karamanlıların hem sağ hem de sol kolları tamamen bozulmuş etrafta neredeyse kimse kalmamış, Alaeddin Bey bu durumu firsat bilen Timurtaş Paşa’nın ani hücumuyla zor durumda kalınca kaçarak Konya kalesine kapanmıştır. ${ }^{49}$

49 İbn Kemal, III. Defter, s. 66-68. Bunun devamında Murad'ın Müslüman halkı incitmemek için kat'i emir verdiği, hiç kimsenin malına dokunulmadığı, ancak birkaç Sırp askerinin ordudan uzaklaşarak Müslüman köylüleri sıkıştırıp onlardan zorla yiyecek maddeleri aldıkları, bazılarına eziyet ettikleri, bu şikayetlerin ulaşması üzerine I. Murad'ın bunları herkesin gözü önünde cezalandırdığı, Konya civarında 12 gün kaldığı sonra kızının aman dilemesi üzerine Alaeddin Bey’i affettiği ve böylece Karamanlıların bir bakıma Osmanlı vasali haline geldiği vurgulanır. Alaeddin Bey için şunları yazar: I. Murad, "..sâbıka taht-ı eyâletinde olan vilâyette emâret emrini yine kendüye mukarrer etti..” (I, 68-71). İdris-i Bitlisî bu kısımda aynen şunları yazar: “...Las ordusundan bazılarından böyle bir el uzatma hadisesi zuhura gelmişti. Adaleti sağlamak ve o zulmü def etmek için reaya ve acezeye el uzatan bu birkaç kişi de idam edilmişti. Zulm edebilecek diğerleri için ibret olmuştu. Memleket ahalisi Sultan'ın adaleti ve merhameti sayesinde refaha kavuştular. Konya şehrindeki birkaç hücumun ardından Karaman valisi Sultan'ın hisarı fethedeceğini, kendi hükümetini ve hanedanını kökünden sökeceğini anlamıştı. Zira hisardaki asker ve muhafızlar arasında bir zayıflık baş göstermişti. Sultan'ın galip geleceği aşikârdı. Her ne kadar yaptıklarından ötürü pişmanlık duysa da, giriştiği kötü işlerden dolayı özür dilese de kurtulacağını ümit etmiyordu. Yine de Sultan'ın melek huylu oluşuna ve iyi ahlakına güveniyordu. Kusurunun affedilmesi için iftiharu'l-havâtîn, bakiyyetu'l-havâkîn Sultan Hatun'u -ki Sabiye Sultan idi- arac1 olarak seçmişti. Onun yanına da ehl-i fazıl kimselerden, ulemadan ve imamlardan oluşan bir güruhu tayin etmişti. Sabiye Sultan, hilafet ve merhamet-şiar babasının hizmetine varınca babasının evladına karşı olan şefkat duygularını kıpırdattı. [Sabiye Hatun] kocasının toz içinde bıraktığı Sultan'ın kalp ve gönül aynasını ağlama ve sızlama ile parlattı. Lütufkâr Sultan akrabalarınızı ziyaret ediniz mazmunu gereğince evladının bu yalvarışlarını dikkate alarak onun kocası olan Ali Bey'in bütün eski suçlarını bağışladı. Cezalandırmaktan vazgeçip ona ihsanlarda bulunmaya meyl etti. Şöyle kararlaştırıldı: Ali Bey hisardan dışarı çıkacak, Sultan'ın elini öptükten sonra anlaşma şartları yenilenecekti. Karaman eyaleti eskiden olduğu gibi yine ona verilerek akranlarından daha imtiyazlı bir konuma getirilecekti. Sultan ahdine vefa göstermede bütün meliklerden daha sadık olduğu için Ali Bey onun bu sözlerine itimat ediyordu. Böylece sultanların sığınağı olan onun bargâhını öpmeye yöneldi. Sultan onun utançlık içinde olan tozlu yanağını parlattı. Kahr ve intikam atının dizginlerini cezalandırma yönünden kendi kendi lütuf ve merhamet eliyle çekti. Bu korku cenderesinden çıkarıp emn ü emana vardırdı. Miras olan memleketini yeniden ona bağışladı. Karaman hükümetinin anahtarlarını ona geri verdi. Ahd ü peymanı yenileme ve ittifak temellerini sağlamlaştırmaya koyuldu..." (vr.152b: Bu kısmın ve ayrıca ekteki mektubun tercümesini yapan Vural Genç'e teşekkür ederim). 
Bu ifadeler fark edileceği üzere Neşrî̀nin kaynağındaki savaş tasviriyle yer yer örtüşse de ondan biraz daha ayrıntılıdır. İbn Kemal savaşı, daha düzgün ve ayrıntıları hazf etmeyerek nakletmeye itina göstermiştir. Onun anlatımı, Neşrînin daha kısa kestiği anlaşılan kaynağındaki bilgilerle aynı zeminde ilerler. Bu bakımdan İbn Kemal, Neşrî̀yi doğrudan değil muhtemelen onun kaynağını ondan bağımsız olarak görmek suretiyle ve yer yer kendisine göre genişleterek bu kısmı yazmıştır. Buradaki her iki anlatım da netice itibarıyla öncesindeki ve sonrasındaki savaş sistemleriyle karşılaştırıldığında Osmanlı ordu sisteminin benzerlerine göre giderek farklılaştığını ve başarıların da bir ölçüde buna dayandığını düşündürmektedir.

\section{Şikârînnin Alternatif Savaş Anlatımı}

Bütün bu anlatılan seferin ve savaşın yegâne kaynağı Neşrînnin metnine karşı, savaşın Karamanlıların bakış açısıyla kaydedildiği geç tarihli bir eser olan Şikârînin Karamannâmesi, alternatif bir anlatım sunsa da Karamanlıların mağlubiyetini üstü kapalı şekilde kabul eder. Bu ilginç alternatif metinde olaylar ters yüz edilerek barış isteyenlerin Osmanlılar olduğu noktası öne çıkarılır ve Murad'ın bu savaştaki perişanlığı söz konusu edilir. Güvenilir olmamakla birlikte bu metinden bazı önemli bilgiler elde edilebilir; ama bu olayın en doğru anlatımının yine de Neşrî̀deki metinde olduğu ve büyük ihtimalle bir görgü şahidinin ifadelerinin yer yer abartılı da olsa esası teşkil ettiği gerçeğini hatırdan uzak tutmamak gerekir.

Şikârî, olayları çok karışık ve takdim tehirlerle nakleder. Onun bu ilk savaşın sebeplerini izah ederken Germiyan ve Hamid-ili beyinin aradaki siyasi manevralarına vurgu yapması önemli görünür. Burada Kütahya ve Eğridir’in ele geçirilmesi, Hamid-ili'ne Osmanlıların tamamen hakim olmasının ortaya koyduğu gerilime temas edilmekte olması ilginçtir. Şikârî̀nin metninde Karamanlı üstünlügü bu vesileyle de sık olarak tekrarlanır. Orada I. Murad'ın "gazâya mâni" olan Karamanlılar tezine karşı, "küfrân-ı nimet" eden Osmanlı iddiası ön plana çıkarılır. Çünkü Şikârîye göre Osmanlı hanedanının kurucu atası Osman Bey’in ortaya çıkışında Karamanlar'ın rolü vardır. "Bî-asıl" olan yani soyu belli olmayan yahut önemli bir asaleti bulunmayan Osman’ı Karamanoğlu korumuştur, hatta onu Germiyanlılar birkaç defa esir almıs, her defasında Karamanlılar'ın araya girmesiyle kurtulmuştur. Karamanlılar onu tabl ve alem sahibi yapmışlardır. Şimdi ise Osman'ın ahfadı iyiliğe karşı düşmanca davranmaktadır. Alaeddin Bey 
Osmanlıların düşmanca hareketlerini işitince şöyle demiştir: "iyiliğe iyilik olsa öküze bıçak olmazdı". ${ }^{50}$

Şikârî̀ yapılan savaşı birkaç safhada anlatmayı tercih eder. Ona göre önce çarhacılar çatışmış, sonra Turgutoğlu Ali Bey meydana çıkarak Murad'ı suçlamış, "Kostantin tekfurundan" iki kafir beyinin çerileriyle gelmesini kınamış, ${ }^{51}$ Müslüman olana kafir askerinin yardım etmesinin uygunsuz olduğunu söylemiştir. $\mathrm{Bu}$ anlatılanlar Osman Bey'in Balkanlı vasallerinin orduda bulunduğunu ifade eden Neşrî̀nin kaynağının anlatımını destekler. Alaeddin savaş sırasında Moğol beylerine, Osmanlı kumandanlarından Kutlu ve Timurtaş่ı hedef almalarını tembih etmiştir. Bu isimler Neşrî̀de de geçmektedir. Savaş tavsifinde ise Şikârî Karamanlılar'ın üstünlüğünü vurgular, savaşta Timurtaş yaralanmıştır. Onu gören Germiyanoğlu harekete geçer, fakat Karaman tarafında onu Bulgar ve Gülnar askerleri karşılar. Göğezoğlu, Germiyan beyi Alişiri zor durumda bırakır, fakat Alişir’in imdadına Hamidoğlu İlyas Bey yetişir. Bu anlatım yine Neşrî̀nin kaynağıyla paralellik arz eder. Zira Osmanlı ordusunda Germiyan birlikleri, Timurtaş'ın idaresindeki orta kesimde yer almıştı. Neşrî̀nin kaynağında Hamidoğlu zikredilmemekle beraber, Eğridir subaşısının askerlerinin mevcudiyeti, Hamid-ili'ne ait bir kısım birliklerin Osmanlı ordusunda hazır bulunmuş olma ihtimalini kuvvetlendirir.

Şikârî Osmanlı kaynaklarının aksine bu çarpışmaların üç gün boyunca sürdüğünü, dördüncü günü Kosunoğlu ile Davud Bey’in saldırıya geçtiğini, Alaeddin Bey'in ise cenge girmeksizin mücadeleyi uzaktan seyretmekle yetindiğini bildirir. Ona göre Murad Bey "zebun" olur, yenilir sulh ister, fakat Davud Bey sulhü önler, bozulan askere son darbeyi vurma fırsatının yakalandığını söylerse de Alaeddin Bey buna izin vermez. Murad ile anlaşmaya taraftar olur, bunun karşılığında Osmanlı ailesinden bir "oğlanı" rehin alır ve Beyşsehir kalesine hapseder, ${ }^{52}$

50 Şikârî, Karamannâme, nşr. M. Sözen-N. Sakaoğlu, İstanbul 2005, s. 208.

51 Metindeki ibare "tekfur-1 Kostantin'den iki kâfir beyi” şeklinde olup ilk anda Bizans imparatorunun kastedildiği zannedilir. Ancak bunların Sırp askerleri olduğu ve yanlış bir tanımlamayla metne dahil edildiğine şüphe yoktur. Yani Şikârî de Osmanlı ordusundaki Sırp yardımcı kuvvetlerden bahseder ve iki bey olarak tanımı daha açık hale getirir (Karamannâme, s. 209).

52 Şikarî bu arada Murad'ın kardeşi Mustafádan söz eder, ama Mustafa Murad'ı Karamanoğlu ile savaşmaktan alıkoymaya çalışır, hatta Karamanoğlu ile buluşur (Karamannâme, s. 208). İlerleyen sayfalarda Şikarî Beyşehir'de hapsedilen "oğlan”ı Murad'ın kardeşi olarak tanıtır. Bu durumda hapse atılanın Mustafa olması düşünülebilir. Fakat bu hadisenin bir senaryodan ibaret olduğu açıktır. 
ardından da geri çekilmesine müsaade eder. Şikârî bu şekilde savaşı Karamanlıların başarısıyla nihayetlenmiş olarak anlattıktan sonra başka çarpışmalara da yer verir.

Aradan iki yıl geçtikten sonra yeniden Murad'ın, Germiyanoğlu ile Eşrefoğlu’nun çağrısı uyarınca geldiğini yazar. I. Murad, Germiyanlılarla birleşip Akşehir'e gelmiştir. Alaeddin'e haber ulaşınca "İbn Osman” ın ahde vefasızlığından dem vurur, hatta bu yolda mektup yazar, burada bir de fetvaya yer verir. Mektupta "müslümanın müslümana kılıç çekmesinin dinen yanlış" olduğuna vurgu yapılmaktadır. ${ }^{53}$ Bununla birlikte Murad bunu dinlemez, fetvaları parçalar, cenge hazırlanır. Murad savaşta zor duruma düşerse de Moğol beylerinden yardım ister. Moğol beyleri (Galince, Esen, İsa) Alaeddin’in de kendilerinden yardım isteği karşısında kimi tercih edeceklerini söyleşirler ve sonunda Murad'ı seçerler, savaşa ağırlıklarını koyarak Alaeddin' in yenilmesine yol açarlar. Savaş yedi gün sürer. Alaeddin yenilince Konya’ya döner ve kaleye kapanır. Murad gelip Konya’yı kuşatır, ancak Alaeddin’in yardım istediği birlikler (Davud Bey, Kaya Beyoğlu Erdoğdu, Kosunoğlu) yetişir, kendisi de askeriyle dışarı çıkar ve Konya önlerinde Osmanlı ordusunu dağıtır. Murad yine muhasara altındadır, bu defa Süleyman Paşa onun için yine "bî-asıldır ve han oğlu değildir" deyip eğer fırsat bulsalar babalarını bile katledecek tıynette olduklarını "mürüvet" yani insaniyet/ yiğitlik nedir bilmediklerini söylerse de Alaeddin âlicenablık gösterip yenilmiş birine kıymanın "mürüvet" olmayacağını ifade eder ve Murad'a bir kurtulma firsatı tanır. Murad da askerleriyle buradan çıkıp kaçar. Sonra Akşehir önüne gelir, Sultandağı'na çıkar, buradan sürekli Konya’yı takip etmeye başlar. Alaeddin Bey, oğlu Mehmed ile dügün ve eğlence meclisindedir, Timurtaş Paşa Karamanoğlu üzerine varmaktansa Beyşehir'i vurup rehin olarak orada tutulan Murad'ın kardeşinin (Mustafa ?) kurtarılması fikrini ileri sürer. Murad, Kutlu ve Timurtaş ile Beyşehir'e gelip kaleyi alır, kardeşini kurtarır, ayrıca bu civarda dört parça kale daha alır, sonra Bursa'ya döner. Şikârî bu vesileyle Germiyanoğlu ile Alaeddin’in konuşmalarına yer verir. Germiyan beyi şöyle söylemiştir: "Sultanım bu hususta suç senindir, bir çoban iken Yörük oğlu iken tabl ve alem verdin, ben dört kere habs eyledüm, muradım helâk etmekti, sen benimle onun için ceng eyledin..." ${ }^{4}$

53 “Müslüman Müslümana kılıç çekmek hangi kitapta vardır? Müslüman kâfir askerinden yardım alıp Müslümanlar kırmağa gelmek hangi mezhepde vardır.. fetvâları yanında olan ulemalara okudasın göreler din-i Muhammed'e eyledügün fiiller var midır?" (Karamannâme, s. 210).

54 Karamannâme, s. 211-213. 
Kısaca anlaşılacağı üzere Şikârîde yer alan ve iki parçalı olduğu anlaşılan metin aslında birbiriyle aynı hadiseyi naklediyor olmalıdır. Şikârî ikinci metinde Alaeddin Bey'in mağlubiyetini ve Murad'ın Konya'yı muhasarasını kabul eder bir anlatım ile ama olayları Karamanlıların lehine gelişmiş şekilde aktarmayı tercih etmiş görünür. Verdiği bilgilerde Neşrî̀nin kaynağıyla yer yer örtüşmeler vardır, bununla beraber hadiseyi iki ayrı olay halinde aralarında iki yıllık bir fasıla olduğu halde göstermekte bulunması söz konusu bilgilerin güvenilirliğini önemli ölçüde sarsmaktadır. Yine de bu metin karşı tarafın bakışı itibarıyla olayın nasıl algılanmış olduğunu anlamak bakımından iyi bir örnek oluşturur. Öte yandan Karamanlılar'ın Osmanlılara bakışındaki küçümsemeye yönelik ibarelerin devamlı tekrar edilmesi hayli manidardır. Bu ise iki rakib beyliğin üstünlük mücadelesinde devreye soktukları propagandanın mahiyeti hakkında son derece açılkayıcıdır.

Netice olarak Osmanlı savaş tarihinde bugüne kadar önemi pek farkına varılmamış olan Frenkyazısı Savaşı yla başlayan gelişmeler, Anadolu'da I. Murad'ın üstünlüğünü teyid ettiği gibi beylikleri onun vasali haline getiren süreci de başlatmıştır. Bunun en çarpıcı örneği Frenkyazısı Savaşı'ndan bir-iki yıl sonra Murad'ın I. Kosova savaşına giderken içlerinde Karamanlı askerlerin de bulunduğu bütün vasallerinin ordusunda bulunması keyfiyetidir. Sadece bu durum bile Karamannâme' nin hadiseleri nasıl kendi zaviyesinden çarpitarak vermiş olduğuna iyi bir örnektir. Karamanoğulları'nın üstünlüğünü meşru zeminlerde vurgulamaya itina eden Karamannâméye karşılık Osmanlı tarafinda da Karamanlılar'ın Osmanlılara tâbi bir durumda oldukları argümanı geliştirilmiştir. Özellikle Karamanoğulları'nın gücünün kırıldığı ve ortadan kalktığı zamana ait Osmanlı kroniklerindeki temel söylem, onların daha ilk dönemlerdeki hareketlerinin "isyan” olarak nitelenmesidir. Gayet iyi bilindiği gibi özellikle de hiç olmazsa 1386' ya kadar olan devre için Karamanoğulları'nın tâbiliği diye bir husus söz konusu değildi ve karşılıklı rekabet ve savaşlar da Karamanlılar için bir "metbuya karşı isyan” hususiyeti taşımıyordu. Öte yandan Frenkyazısı Savaşı aradaki mevcut dengeye bir son vererek, Karamanoğulları tarihi açısından tam bir dönüm noktası oldu; Osmanlı hakimiyetinin ilk kuvvetli adımlarının atılmasının önünü açtı. Sonraki dönemlerde Osmanlılar -kısa ara dönemler hariç- diğer bütün Anadolu beylikleri üzerinde kati bir merkezi otorite kurdularsa da Karaman beyliğini kendi başına tâbilik ve bağlılık şartıyla yerinde bırakmayı, askeri ve stratejik gerekçelerle uygun gördüler. Bu durum ancak İstanbul'u alan Fatih Sultan Mehmed'in yeni siyasetinin devreye girişiyle değişecektir. 


\section{EK:}

Münşeatüs-Selâtîn, I, 108-110: Ahmed Celayir'e Yollanan Frenkyazısı Beşaret-nâmesi.

"Cennet-mekân Sultan Murad Han Gazi Hazretleri Tarafindan Karamanoğlu Ali Bey'in İnhizamında Băğdad ve Azerbaycan Hâkimi Sultan Abmed Celâyirîye Yazılmus Olan Nâme-i Hümâyûn Sûretidir"

[s. 108] Bismillahirrahmanirrahim. Yardım ancak Allah katındandır. Doğrusu Allah güçlüdür, hakimdir. ${ }^{1}$ Hamd ü sena sebepsiz bağışlarda bulunan o bağışlayıcı hazrete, (vâhib-i bi- illet), kellemtuhủnun (Onunla konuştum) sebebine (illet-i kellemtuhu) farz ve lazımdır ki bu cömert bedenimizi [s. 109] Gerçekten biz seni yeryüzünde bir halife yaptı $k^{2}$ hilatiyle süslemiş, yüce himmetimizi fesadları def ve beldeleri feth yolunda bütün kullardan daha fazla imtiyazlı konuma getirmiştir. Din-i metin-i Muhammedî̀nin desteğinin ve Şeriat-1 mübîn-i Ahmedî̀nin geleneğinin salat ve selam onu vaz' edenin üzerine olsun bereketiyle bizim kutlu hareketimizi büyük fetihlerin ve sevinçlerin gerçekleşme sebebi yapmıştır. Birçok memleketi kefere-i fecerenin tasarrufundan çıkarıp fethettikten sonra bizim etrafımızda olan İslam hâkimlerinin çoğu itaat halkasını boyunlarına takmakla ve bizim sınırsız ihsan ve inamlarımızdan faydalanmakla müşerref oldular. Âl-i Germiyan ile kutlu oğlu Yıldırım Bayezid Allah onun ömrünü uzatsın arasında evlilik vuku bulunca Karamanoğlu Ali Bey de bu duruma gıpta edip türlü tazarrularda bulunarak kendisini benim evlatlarım zümresine dâhil etmişti. Böylece bizim bu konuda ona olan kutlu itimadımız artmış oldu. Bunun üzerine hemen Rumeli gazasına yönelme emri verdim. Yolun daha yarısında iken adı geçen Ali Bey’in bu akrabalık bağını kopardığı, Hamid hâkiminden satın aldığımız bazı belde ve köylerin tamamını yağmalayarak korkunç bir edepsizlik yaptığı haberi geldi. En iyisi geri dönmek tercihini göz önüne alarak Karaman beldelerine vardık. Onun bu meşru olmayan davranışlarına kayıtsız kalmayıp Bir kötülü̈̆̈̈̈n cezası da onun misli bir kötülükledir muktezası gereğince onu mükâfatlandırmak için Hak'tan nusret talep ettik. 788 senesi Şevval ayının 25. Çarşamba günü bu yola baş koyup sadece ilahi lütuflara sarılarak mücahitlerle, kutlu evlatlarla, Rumeli ve Anadolu beylerbeylerinin, sair ümeranın ve yüce soylu zaimlerin askerleriyle, yeniçeri ve azapların saflarıyla -Allah onlara yardım etsin ve desteklesin- Mahmiye-i Konya'ya iki fersah mesafede zafer alametli sancaklarımızla

1 Kur'an: 8/10.

2 Kur'an: 38/26. 
hazırlandık. Müşîr-i ekrem, veziriazam Ali Paşa'yı -damet maalihu-ordunun önüne tayin ettik. Karamanoğlu Ali Bey'in de savaşa girişmesi fırsatını kolluyorduk. [Ali Bey] ordusunun sağ ve sol kanadını Turgudlular, Varsağlılar, kalabalık Türkler ve çirkin görünümlü ayaktakımı ile doldurmuştu. Veziriazam ise ordunun en ön saflarında elindeki gürzü düşmanlarından esirgemiyordu. Sıra Rumeli beylerbeyi yemînüd-devle Timurtaş Paşa’ya -dame uluvvuhu-geldi. O da bu yolda dakika ziyan etmeyerek mertçe savaştı. Sol kanattan Anadolu beylerbeyi Saruca Paşa -dame ikbaluhu-hiç durmadı. Bizi kötü amelli düşmanın zamanından çıkardılar. ${ }^{3}$ Ali Bey sağ ve solunun dağılmış ve yenilmiş vaziyette olduğunu görünce baş aşağı olmuş sancaklarıyla ordunun kalbine hücum etmek istedi. Yardım bulmuş kutlu evlat Yıldırım Bayezid Han -Allah onun ömrünü arttırsın ve kadrini yükseltsin- yıldırım gibi parlayan kılıcıyla düşmanların üstüne vardı. Şahlara yakışır bir hamle ile onları mağlup ederek Konya Kalesi'nin içine kadar onları kovaladı. Düşman yenilmiş bir şekilde hisara kaçınca saadet alametli gaziler sınırsız ganimete kavuştular. Bütün ümera ve askerlere kalenin etrafını muhasara etmelerini ferman ettik. Ali Bey hemen yalvaran dilini uzatıp, şefaat talep eden elini bizim merhamet eteklerimize dolayarak özür diledi. Biz de kavmin vaktiyle aziz olan ve sonra zillete düşen insanlarna rahmet ediniz mazmunu gereğince onun hatasını bağışladık. O vilayeti tekrar ona verdik. Beş vakit namazda hidayetiyle bizi (bu nimete) kavuşturan Allah'a hamdolsun! ${ }^{4}$ manasını dilimizden düşürmeyip saltanat karargahına geri döndük. Bu beşâretnâmeyi 'umdetü'l-emâcid ve'l-ekârim Abdülkerim Çavuş -zide kadrubu- eliyle nime'lmeâb canibine gönderdik ki bu durumdan haberdar olasız ve oranın ahvalini bildiresiz ki onunla teselli olalım. Günlerin ve gecelerin dönüşü [s. 110] o kutlu talihli şehriyarın meramına uygun olsun! Cömert olan Allah'ın lütfuyla.

\section{el-cevab (Ahmed Celayir'in cevabı)}

...âli-hazret, felek-menzilet, Süreyya-mertebet, padişah-1 gerdûn-pâye, hümâ-sâye ve şehinşâh-1 hurşîd-vâye, lutf-pîrâye noyan-1 a’zam, hüdavendigâr-1 muazzam, melik-i mülûkü'l-ümem, sultanu'l-Arab ve'l-Acem, hakanü't-Türk ve'd-Deylem, gıyasü'l-islam ve'l-Müslimîn, el-kâim bi-emrillah, el-gazi fi sebilillah, el-müeyyed min indillah Ebu'n-nasr Sultan Murad...

3 Metindeki ifade bu şekildedir. Burada muhtemelen düşmanın baskısından, tehlikesinden kurtulma anlamı söz konusudur.

4 Kur'an: 7/43 
$\mathrm{Bu}$ tahiyyat 790 senesinin Rebiyülevvel ayının başında kaleme alındı. Yani kötü akibetli kardeş olan Hüseyin'in hezimete uğratılmasından sonra.

(Satırların devamında iki taraf arasındaki dostluğun devamı temennileri var. Uzun zaman o taraflardan haber beklerken ansızın sultanın elçisi Abdülkerim Çavuş่un Karamanlıların yaptığı küstahlıklar karşısında alınan intikamı bildiren haberlerle geldiğini beyan ediyor.)

Öz @ Osmanlı tarihinin kaynaklara dayalı ilk büyük meydan savaşı anlatımı I. Murad devrine kadar iner. I. Kosova savaşından hemen önce Osmanlılarla Karamanlılar arasında meydana gelen Frenkyazısı Savaşı (1386 sonu 1387 başları) ile ilgili ayrıntılı bir "zafernâme/fetihnâme" metni, XV. asra ait ilk Osmanlı kroniklerinden Neşrî tarihinin içinde yer alarak bugüne ulaşmıştır. Yine erken Osmanlı tarihçilerinden Âşıkpaşazâde'nin muhtemelen farklı saiklerle temas bile etmediği bu savaşla ilgili metin, Neşrî̀nin yanında ondan biraz sonra eserlerini kaleme alacak olan İbn Kemal ile İdris-i Bitlisi'nin eserlerinde de yer almaktadır. Onlarla çağdaş Behişti'nin eserinde ve Anonim Osmanlı kroniklerinden bir kısmında daha muhtasar olarak savaştan söz edilmektedir. Bununla beraber Neşrî, İdris-i Bitlisî ve İbn Kemal'in eserlerindeki anlatımlar birbirinden mülhem değil müşterek bir başka metne dayalı olmalıdır. Karamanlılar tarafından hadiseye bakan XVI. asra ait Şikarînin Karamannâme’sinde ise alternatif farklı bir metne yer verilir. Burada anlatılanlar, ayrıntılar bakımından değil ama ana hatları itibarıyla diğer metinlerle kısmen de olsa örtüşür. Kroniklerdeki bilgiler, I. Kosova savaşı öncesi, Frenkyazısı muharebesinin Osmanlı klasik savaş sistemi içindeki değişimini göstermesi bakımından ayrı bir kıymeti haizdir. Her şeyden önce bu metinlerden öğrenilen husus, Osmanlı tarafının piyadeye dayalı gücü ve sistemi ile klasik Türkmen savaş taktikleri arasındaki farklılaşmanın ortaya çıkışıdır. Ayrıca savaşın siyasi sonuçları, Karamanlıların Osmanlı üstünlüğ̈̈nü kabul etmelerinin yolunu açmıştır.

Anahtar kelimeler: Osmanlı-Karaman ilişkileri, Osmanlı savaş sistemi, Frenkyazısı Savaşı, I. Murad, Karamanlı Alaeddin Bey, Konya. 


\section{Kaynaklar}

Atsız, Hüseyin Nihal: "Hicri 858 Yılına Ait Takvim”, Selçuklu Araştırmaları, 4 (1975), s. 223-83.

Atsız, Hüseyin Nihal: Dokuz Boy Türkler ve Osmanlı Tarihleri, İstanbul: Arkadaş Basımevi 1939.

Atsız, Hüseyin Nihal: Osmanlı Tarihine Ait Takvimler, Atsız neşri, İstanbul: Küçükaydın Matbaası 1961.

Aziz b. Erdeşir-i Esterâbâdî: Bezm ü Rezm, çev. Mürsel Öztürk, Ankara: Türk Tarih Kurumu Basımevi 1990.

Başkan, Yahya: "Karamanoğulları Beyliği Alaeddin Ali Bey Dönemi, 1357-1398”, Karaman Tarihi ve Kültürü, III, Konya [Karaman Valiliği]: (baskı yeri ve tarihi yok), s. 381-462.

Behiştî Ahmed Çelebi: Târîh-i Behiştî: Vâridât-ı Sübhânî ve Fütûhât-ı Osmânî (791907/1389-1502), II, haz. Fatma Kaytaz, Ankara: Türk Tarih Kurumu 2016.

Behiştî Ahmed Sinan: Târîh-i Âl-i Osmân, İstanbul Araştırmaları Enstitüsü Ktp., Şevket Rado Yazmaları, nr. 293.

Beldiceanu-Steinherr, Irene: Recherches sur les actes règnes des sultans Osman, Orkhan et Murad I, Monachii/Münih: Societatea Academică Română 1967.

Emecen, Feridun M.: “İhtirasın Gölgesinde Bir Osmanlı Sultanı: Yıldırım Bayezid”, Osmanlı Araştırmaları, 43 (İstanbul 2014), s. 67-92.

Emecen, Feridun M.: “İlk Osmanlı Savaşları ve Taktikleri”, Osmanlı Klasik Çăğıda Savaş, İstanbul: Timaş Yayınları 2015, s.15-25.

Emecen, Feridun M.: “Timurtaş Paşa, Kara”, TDV İslâm Ansiklopedisi, XLI (Ankara 2012), s. 185-86.

Emecen, Feridun M.: Osmanlı İmparatorlü̆u’nun Kuruluşve Yükseliş Tarihi (1300-1600), İstanbul: Türkiye İş Bankası Kültür Yayınları 2015.

Feridun Bey: Münşeatüs-Selâtin, I, (İstanbul, 1274).

Genç, Vural: Acem'den Rum'a: İdris-i Bitlisî̀nin Hayatı, Tarihçiliği ve Heşt Behişțin II. Bayezid Kısmı (1481-1512), (Yayınlanmamış Doktora Tezi) İstanbul Üniversitesi Sosyal Bilimler Enstitüsü, 2014.

Hoca Sadeddin Efendi: Tâcüt-tevârih, I (İstanbul, 1279).

İdris-i Bitlisî: Heşt Bihişt (Abdülbaki Sadi Efendi tercümesi), M. Karataş-S. Kaya-Y. Baş (haz.), Ankara: Betav Yayınları 2008.

İdris-i Bitlisî: Heşt Bihişt, Nuruosmaniye Ktp., nr. 3209. 
İnalcık, Halil: Has-bağçede Ayş u Tarab: Nedimler Şâirler Mutribler, İstanbul: Türkiye İş Bankası Kültür Yayınları 2011.

İnalcık, Halil: Kuruluş Dönemi Osmanlı Sultanları (1302-1481), İstanbul: İSAM Yayınlar1 2010.

Kemal: Selâtin-nâme, haz. N. Öztürk, Ankara: Türk Tarih Kurumu 2001.

Kemalpaşazâde (İbn Kemal): Tevârih-i Âl-i Osman, III. Defter, Abdullah Satun (haz.), İstanbul: Çamlıca Yayınları 2014.

Kofoğlu, Sait: "Hamidoğulları", TDV İslàm Ansiklopedisi, XV, (Ankara, 1997) s. 473-474.

Kuzev, Alexander: "Die Beziehungen des Königs von Vidin Ivan Sracimir zu den osmanischen Herrschern", Etudes balkaniques, 7/III (1971), s. 121-124.

Mehmed Neşrî: Cihannümâ, N. Öztürk (haz.), İstanbul: Bilge Kültür Sanat 2013.

Mehmed Neşrî: Kitâb-ı Cihannüma, R. Unat - M. A. Köymen (haz.), Ankara: Türk Tarih Kurumu Basımevi 1987, I.

Minorsky, V.: "Üveys”, MEB İslâm Ansiklopedisi, XIII, s. 133-134.

Ölçer, Cüneyt: Karamanoğulları Beyliği Madeni Paraları, İstanbul: Yenilik Basımevi 1982.

Reinert, Stephen W.: "Niş’ten Kosova’ya: I. Murad'ın Son Yıllarına İlişkin Düşünceler", E. Zachariadou (ed.), Osmanl Beyliği (1300-1389), İstanbul: Tarih Vakfı Yurt Yayınlar1, 1997, s. 183-230.

Sümer, Faruk: "Alaeddin Bey”, TDV İslâm Ansiklopedisi, II (Ankara 1989), s. 321-23.

Şikârî: Karamannâme (Zamanın Kahramanı Karamanîlerin Tarihi, Metin Sözen, Necdet Sakaoğlu (nşr.), İstanbul: Karaman Valiliği - Karaman Belediyesi Yayınları, 2005.

Tekindağ, Şehabettin: "Karamanlılar'ın Gorigos Seferi (1367)", Tarih Dergisi, 6 (İstanbul 1954), s. 161-174.

Turan, Osman: İstanbul'un Fethinden Önce Yazılmıs Tarihi Takvimler, Ankara: Türk Tarih Kurumu Basımevi 1984.

Uzunçarşıll, İ. H.: Osmanlı Tarihi, Ankara: Türk Tarih Kurumu Basımevi 1995, I.

Yücel, Y. - Cengiz, H. E.: "Ruhi Tarihi-Oxford Nüshası", Belgeler, XIV/18 (Ankara 1992), s. $359-472$.

Yücel, Yaşar: Kadı Burhaneddin Ahmed ve Devleti,1344-1398, Ankara: Türk Tarih Kurumu Basımevi 1970. 